\title{
Bacterial Whole Cells Synthesis of Whisky Lactones in a Solid-State Fermentation Bioreactor Prototype
}

\author{
Dawid Hernik $^{1, *(\mathbb{D})}$, Jakub Pannek ${ }^{1,2}$, Ewa Szczepańska ${ }^{1} \mathbb{D}$, Teresa Olejniczak ${ }^{1} \mathbb{D}$ and Filip Boratyński ${ }^{1, *(\mathbb{D})}$ \\ 1 Department of Chemistry, Wrocław University of Environmental and Life Sciences, Norwida 25, \\ 50-375 Wrocław, Poland; jakub.pannek@rdhub.pl (J.P.); ewa.szczepanska@upwr.edu.pl (E.S.); \\ teresa.olejniczak@upwr.edu.pl (T.O.) \\ 2 R\&D Hub Spółka Z Ograniczoną Odpowiedzialnością (sp. z o. o.), Spokojna 10, 98-270 Złoczew, Poland \\ * Correspondence: dawid.hernik@upwr.edu.pl (D.H.); filip.boratynski@upwr.edu.pl (F.B.)
}

Citation: Hernik, D.; Pannek, J.; Szczepańska, E.; Olejniczak, T.; Boratyński, F. Bacterial Whole Cells Synthesis of Whisky Lactones in a Solid-State Fermentation Bioreactor Prototype. Catalysts 2021, 11, 320 https://doi.org/10.3390/ catal11030320

Academic Editor: Evangelos Topakas

Received: 31 December 2020

Accepted: 25 February 2021

Published: 1 March 2021

Publisher's Note: MDPI stays neutral with regard to jurisdictional claims in published maps and institutional affiliations.

Copyright: (c) 2021 by the authors. Licensee MDPI, Basel, Switzerland. This article is an open access article distributed under the terms and conditions of the Creative Commons Attribution (CC BY) license (https:/ / creativecommons.org/licenses/by/ $4.0 /)$.

\begin{abstract}
Agro-industrial side streams such as oilseed cakes were used as a medium in solid-state fermentation (SSF) for microbial oxidation of anti- and syn-3-methyl-octane-1,4-diols to obtain corresponding trans- and cis-whisky lactones. In preliminary screening transformations, a wide range of whole bacterial cells were tested on the basis of oxidation activity, which is rarely described in the literature, in contrast to the widely studied lipolytic activity on SSF. Among the different oil cakes tested, biotransformations carried out on linseed cake were characterized by the highest conversion and stereoselectivity. Several preparative-scale oxidations performed in a self-constructed SSF bioreactor catalyzed by Rhodococcus erythropolis DSM44534, Rhodococcus erythropolis PCM2150 and Gordonia rubripertincta PCM2144 afforded optically active trans-(+)-(4S,5R), cis-(+)-(4R,5R) and cis-(-)-(4S,5S) isomers of whisky lactones, respectively. Bacteria of the Rhodococcus, Gordonia, Dietzia and Streptomyces genera carried out transformations with complete conversion after three days. Various extraction methods were applied for the isolation of the products, and among them, the combination of steam distillation with simple extraction were the most efficient. Biotransformations were conducted under precise control of conditions in a bioreactor based on a Raspberry Pi Zero W. The proposed low-cost (ca. USD 100) bioreactor is a standalone system that is fully autoclavable and easy to use.
\end{abstract}

Keywords: biotransformation; microbial oxidation; whisky lactones; diols; solid-state fermentation (SSF); bioreactor; Raspberry Pi

\section{Introduction}

Solid-state fermentation (SSF) is defined as a microbial cultivation process conducted on a solid substrate with a low content of water [1]. Several bioprocesses based on agroindustrial residues, such as the production of enzymes, single-cell proteins, aromas, organic acids, ethanol, biopolymers, and other secondary metabolites, have been developed [2-11]. In both laboratory- and industrial-scale microbial processes, it is essential to control culture conditions such as temperature, moisture content, aeration, and $\mathrm{pH}$ [12]. In comparison to submerged fermentation $(\mathrm{SmF})$, monitoring the aforementioned process parameters during SSF is a challenge because of the solid nature of the substrate. However, due to numerous advantages (low cost of growth media, low energy requirement, low contamination risk, low pollutant production, and high isolation yields), it is worth applying SSF in industry. Of note, SSF use low-cost raw materials such as agro-industrial which significantly lowers the capital investment required for particular bioprocesses in comparison to submerged fermentation, in which liquid media are used [13].

In recent years, attention has been given to significantly reducing the generation of food waste. Agro-industrial residues have special biotechnological potential and can be used to solve this problem. They meet the criteria enabling their use as raw materials for the SSF process, i.e., low water content and optimal particle size allowing penetration of the 
substrate by microorganisms (especially by filamentous fungi) [14]. Oilseed cakes are solid residues obtained as a result of the pressing of oilseeds during vegetable oil production. They can constitute up to $65-70 \%$ of seeds' weight. The oleo industry generates millions of tons of these organic byproducts every year; therefore, focusing on the various processes related to the value addition of oil cakes is needed.

Biotransformation is a process in which microorganisms or isolated enzymes are applied to obtain fine chemicals, such as enantiopure forms of chiral compounds [6,15-17]. Obtaining the desired products by the use of environmentally safe biocatalysts and raw materials makes this approach possible to meet the requirements of sustainable development and green chemistry [18]. Compounds obtained by this method are regarded as natural [19].

The increase in the application of SSF as an alternate production method to SmF by industry has been recently noted $[20,21]$. Despite the progress made in research on the use of SSF, the main obstacle to scaling up the process is the lack of simple, economical and easily scalable bioreactors that eliminate the problem of controlling the process conditions. The basic SSF bioreactors are tray, horizontal drum, packed-bed, and fluidized bed bioreactors, where tray bioreactors have the simplest construction and process performance. The approach proposed in this study constitutes the application of whole-cell biotransformation on oilseed cake as a medium for microorganisms using an upscaled tray bioreactor with sensors controlling the basic culture conditions (temperature and moisture). Due to a number of SSF applications, a new bioprocess involving bacterial oxidoreductases to produce industrially demanded whisky lactone was developed.

Whisky lactone is an essential component of aged alcoholic beverages such as whisky, cognac, and brandy beverages [22]. Presently, it is used as an odor ingredient in various food products (beverages and sweet and baked foods). This commercial food additive contains a racemic mixture of trans- and cis-isomers. However, in nature, individual trans- $(+)-(4 S, 5 R)$ and cis- $(+)-(4 S, 5 S)$ isomers of whisky lactone, which exhibit individual odoriferous properties, occur $[23,24]$. Cis-isomers are described as earthy and woody fragrances, while trans-isomers are reminiscent of celery. Therefore, the manufacture of individual stereoisomers of whisky lactone to study the relationship between its structure and biological activity is necessary. Whisky lactone is not only an aroma; the mixture of cis-and trans-isomers is used as a repellent against mosquitoes and flies [25].

Several stereoselective pathways for the synthesis of individual trans- and cis-isomers of whisky lactone have been presented in the literature [14,26-29]. However, they rely on a multistep chemical synthesis using metal catalysts and organic solvents. Catalysis involving metal compounds is widely engaged in the laboratory and industrial practice. Nevertheless, metal-based catalysts as well as organic solvents also can be dangerous for environment, and significant amounts of them are released to environment annually. The employment of biocatalysts in organic synthesis is seen as the key to green chemistry. It is worth mentioning that the method of obtaining whisky lactone isomers using a non-metallic catalyst has also been described [30]. This process is promising because it is an alternative to metal catalysts, however, it is a multi-step process with a relatively low conversion. Therefore, there is a need for the development of safe procedures that fulfills green chemistry requirements to obtain stereoisomers. To date, two pathways of biotransformation have been proposed: via alcohol dehydrogenase isolated from horse liver (HLADH) enantioselectivity oxidizing racemic syn- and anti-3-methyloctane-1,4diols as well as with the use of Beauveria bassiana AM278 and Pycnidiella resinae $\mathrm{KCH} 50$ microorganisms catalyzing lactonization of $\gamma$-oxo acids. The application of the second strategy allowed us to obtain enantiomerically pure trans-(+)-(4S,5R)-whisky lactone [31].

The study aimed to perform the oxidation of anti-3-methyl-octane-1,4-diol (1a) and syn-3-methyl-octane-1,4-diol (1b) catalyzed by bacteria growing on oilseed cakes. It is worth mentioning that the SSF processes involving oxidation on a solid substrate are not commonly known in the literature. To date, microbial oxidation of xenobiotics performed on oil industry byproducts has been reported with the use of filamentous fungi, which cat- 
alyze stereoselective hydrolysis of a racemic mixture of phenylethyl acetate and subsequent oxidation of 1-phenylethanol to acetophenone [32]. Research on reprocessing waste often requires very large financial contributions, including research equipment. In this article, we described a low-cost bioreactor with a potential environmental impact. To increase the efficiency of whisky lactone production, monitoring of cultivation parameters in the prototype bioreactor was performed.

\section{Results and Discussion}

Substrates for bioxidation, anti- (1a) and syn-3-methyl-octane-1,4-diols (1b), were obtained by chemical reduction of corresponding trans- (2a-b) and cis-whisky lactones (2c-d), which were previously separated by column chromatography (Figure 1). On the basis of our previous experience in the biooxidation reactions [33-35], four bacterial strains (Gordonia bronchialis PCM2167, Rhodococcus ruber PCM2166, Rhodococcus erythropolis DSM44534 and Rhodococcus rhodochrous PCM909) were selected as potential candidates for microbial oxidation of anti- (1a) and syn-3-methyl-octane-1,4-diols (1) b to obtain corresponding trans$(+)-(4 S, 5 R)(\mathbf{2} \mathbf{a})$ and trans- $-(-)-(4 R, 5 S)(\mathbf{2 b})$ or cis- $(-)-(4 S, 5 S)(\mathbf{2})$ and cis- $(+)-(4 R, 5 R)(\mathbf{2} \mathbf{d})$ whisky lactones (Figure 2). The same microorganisms were also used in our recent studies (pending patent protection), in which 3-n-butylphthalide was obtained as a result of oxidation of the corresponding diol (1-hydroxymethyl-2-(1-hydroxypentyl)benzene. Bacteria from selected species were characterized by high activity of alcohol dehydrogenases (ADH) responsible for one-pot oxidation of diols to lactones which was confirmed in our previous studies [33-35].<smiles>CCCC[C@@H](O)C(C)CCO</smiles>

$1 \mathrm{a}$<smiles>CCCCC(O)C(C)CCO</smiles>

$1 \mathrm{~b}$

Figure 1. Structures of anti- (1a) and syn-3-methyl-octane-1,4-diols (1b).

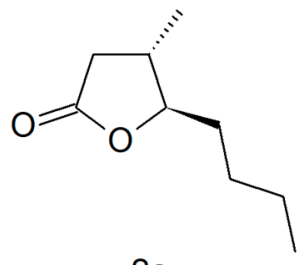

$2 a$

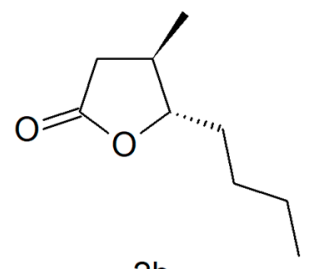

$2 b$

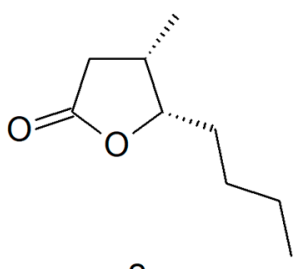

2c

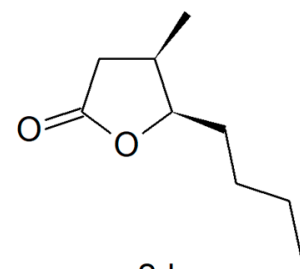

$2 d$

Figure 2. Structures of trans-(+)-(4S,5R) (2a), trans-(-)-(4R,5S) (2b), cis-(-)-(4S,5S) (2c) and cis-(+)-(4R,5R) (2d) whisky lactones.

The growth of biocatalysts as well as the biotransformation process was performed via solid-state fermentation using three different oleoindustry byproducts: linseed, rapeseed and evening primrose cakes. These residues are abundant in nutritional compounds such as carbohydrates, proteins, fats, and cellulose and therefore constitute excellent media for the growth of microorganisms [36,37]. The average moisture of the studied oil cakes $(7.9 \%$ for linseed cake, $6.5 \%$ for rapeseed cake and $4.2 \%$ for evening primrose cake) was calculated by the lyophilization of individual oil cake samples. This confirmed our observation, during which the linseed cake had the highest hygroscopic properties, while the evening primrose cake absorbed water slightly.

\subsection{Preliminary Screening Scale Biotransformations with Anti-3-methyl-octane-1,4-diol (1a) on} Different Oil Cakes

In the oxidation of anti-3-methyl-octane-1,4-diol (1a) with all tested strains growing on the linseed cake, the complete conversion $(c o n v .=100 \%)$ after three days was observed 
(Table 1). Even though cis-whisky lactone was obtained in enantiopure form (ee $>99 \%)$ in all biotransformations, enantiomerically enriched trans-whisky lactone (ee = 20-70\%) was a dominant product.

Table 1. Comparison of microbial oxidation of anti-3-methyl-octane-1,4-diol (1a) on linseed and rapeseed cake (in \% according to GC).

\begin{tabular}{|c|c|c|c|c|c|c|c|}
\hline \multirow{2}{*}{ Strain } & \multirow{2}{*}{ Oil Cake } & \multirow{2}{*}{$\begin{array}{c}\text { Time } \\
\text { [days] }\end{array}$} & \multirow{2}{*}{$\begin{array}{c}\text { Conv. 1a } \\
{[\%]}\end{array}$} & \multicolumn{4}{|c|}{ Products } \\
\hline & & & & $\begin{array}{c}\text { Trans 2a-b } \\
{[\%]}\end{array}$ & $\begin{array}{c}\text { ee } \\
{[\%]}\end{array}$ & $\begin{array}{c}\text { Cis } 2 \mathrm{c}-\mathrm{d} \\
{[\%]}\end{array}$ & $\begin{array}{c}\text { ee } \\
{[\%]}\end{array}$ \\
\hline \multirow{4}{*}{$\begin{array}{c}\text { Gordonia } \\
\text { bronchialis } \\
\text { PCM2167 }\end{array}$} & \multirow{2}{*}{ linseed } & 3 & 100 & $83( \pm 0.7)$ & $33(+)-(4 S, 5 R)-\mathbf{2 a}$ & $17( \pm 1.5)$ & $>99(-)-(4 S, 5 S)-2 \mathrm{c}$ \\
\hline & & 7 & 100 & $81( \pm 1.2)$ & $33(+)-(4 S, 5 R)-\mathbf{2 a}$ & $19( \pm 1.3)$ & $>99(-)-(4 S, 5 S)-2 \mathrm{c}$ \\
\hline & \multirow{2}{*}{ rapeseed } & 3 & $9( \pm 0.9)$ & $7( \pm 0.4)$ & $32(+)-(4 S, 5 R)-2 \mathbf{a}$ & $2( \pm 0.1)$ & 0 \\
\hline & & 7 & $12( \pm 1.1)$ & $10( \pm 0.8)$ & $18(+)-(4 S, 5 R)-\mathbf{2 a}$ & $2( \pm 0.1)$ & 0 \\
\hline \multirow{4}{*}{$\begin{array}{c}\text { Rhodococcus } \\
\text { erythropolis } \\
\text { DSM44534 }\end{array}$} & \multirow[b]{2}{*}{ linseed } & 3 & 100 & $97( \pm 1.2)$ & $20(-)-(4 R, 5 S)-\mathbf{2} \mathbf{b}$ & $3( \pm 0.2)$ & $>99(+)-(4 R, 5 R)-2 \mathbf{d}$ \\
\hline & & 7 & 100 & $90( \pm 0.9)$ & $70(-)-(4 R, 5 S)-\mathbf{2 b}$ & $10( \pm 0.5)$ & $>99(+)-(4 R, 5 R)-2 \mathbf{d}$ \\
\hline & \multirow{2}{*}{ rapeseed } & 3 & $15( \pm 0.7)$ & $8( \pm 0.7)$ & $\mathrm{nd}^{*}$ & $7( \pm 0.2)$ & nd \\
\hline & & 7 & $43( \pm 2.1)$ & $9( \pm 0.8)$ & nd & $34( \pm 1.2)$ & nd \\
\hline \multirow{4}{*}{$\begin{array}{l}\text { Rhodococcus } \\
\text { rhodochrous } \\
\text { PCM909 }\end{array}$} & \multirow{2}{*}{ linseed } & 3 & 100 & $92( \pm 0.7)$ & $20(+)-(4 S, 5 R)-2 \mathbf{a}$ & $8( \pm 0.3)$ & $>99(+)-(4 R, 5 R)-2 \mathbf{d}$ \\
\hline & & 7 & 100 & $90( \pm 0.9)$ & $42(+)-(4 S, 5 R)-2 \mathbf{a}$ & $10( \pm 0.4)$ & $>99(+)-(4 R, 5 R)-2 \mathrm{~d}$ \\
\hline & \multirow{2}{*}{ rapeseed } & 3 & 0 & 0 & 0 & 0 & 0 \\
\hline & & 7 & 0 & 0 & 0 & 0 & 0 \\
\hline \multirow{4}{*}{$\begin{array}{c}\text { Rhodococcus } \\
\text { ruber } \\
\text { PCM2166 }\end{array}$} & \multirow{2}{*}{ linseed } & 3 & 100 & $92( \pm 1.3)$ & $37(+)-(4 S, 5 R)-2 \mathbf{a}$ & $8( \pm 0.1)$ & $>99(-)-(4 S, 5 S)-2 \mathrm{c}$ \\
\hline & & 7 & 100 & $86( \pm 0.6)$ & $33(+)-(4 S, 5 R)-\mathbf{2 a}$ & $14( \pm 0.8)$ & $65(-)-(4 S, 5 S)-2 \mathrm{c}$ \\
\hline & \multirow{2}{*}{ rapeseed } & 3 & 0 & 0 & 0 & 0 & 0 \\
\hline & & 7 & $84( \pm 0.6)$ & $67( \pm 1.2)$ & $5(+)-(4 S, 5 R)-2 \mathbf{a}$ & $17( \pm 1.2)$ & 0 \\
\hline
\end{tabular}

$\mathrm{nd}^{*}$-not determined.

Oxidation with Gordonia bronchialis PCM2167 on linseed cake afforded optically active trans-(+)-(4S,5R)-isomer (2a) $(81-83 \%, e e=33 \%)$ and enantiomerically pure cis-(-)-(4S,5S) whisky lactone (2c) (17-19\%, ee >99\%). In biotransformations performed on linseed cake with Rhodococcus erythropolis DSM44534, R. rhodochrous PCM909 and R. ruber PCM2166, optically active trans-whisky lactone isomers were obtained after three days in amounts of $97 \%$, $92 \%$ and $92 \%$, respectively. It is significant that after 7 days, R. erythropolis DSM44534 produced trans- $(-)-(4 R, 5 S)$-isomer $(\mathbf{2 b})(e e=70 \%)$, while $R$. ruber PCM2166 and $R$. rhodochrous PCM909 gave the opposite trans-(+)-(4S,5R)-isomer (2a) $(e e=33-42 \%)$. The enantioselectivity of biotransformation increases over time; thus, the enantiomeric excess of lactone was higher after 7 days. On the other hand, transformation catalyzed by G. bronchialis PCM2167 afforded higher amounts (ca. 20\%) of enantiomerically pure cis- $(-)-(4 S, 5 S)$ whisky lactone (2c) compared with Rhodococcus strains.

A very low conversion (9 to 43\%) for G. bronchialis PCM2167 and R. erythropolis DSM44534, except oxidation with R. ruber PCM2166 (84\% after 7 days), was observed in biotransformations performed on rapeseed cake. No conversion was observed during the biotransformation with $R$. ruber PCM2166 after three days which indicates that alcohol dehydrogenases are produced by this strain in the later stages of biotransformation. In the bioxidation with $R$. rhodochrous PCM909, no conversion on the rapeseed cake occurred. This indicates that rapeseed cake is an inadequate medium for ADH production by aforementioned biocatalyst. No whisky lactones were detected by using primrose cake for solid-state fermentation; thus, this byproduct is not applicable for diol oxidation.

\subsection{Preliminary Screening Scale Biotransformations with Syn-3-methyl-octane-1,4-diol (1b) on Different Oil Cakes}

During the oxidation of syn-3-methyl-octane-1,4-diol (1) on the linseed cake with all bacterial strains, $100 \%$ conversion was observed after the 3rd day (Table 2). Although 
the transformations catalyzed by Gordonia bronchialis PCM2167, Rhodococcus rhodochrous PCM909 and R. ruber PCM2166 afforded enantiomerically pure trans-(+)-(4S,5R) whisky lactone (ee $>99 \%)$, enantiomerically enriched cis- $(+)-(4 R, 5 R)$ isomer (2d) constituted the majority of the reaction mixture (63-81\%). Biotransformation with G. bronchialis PCM2167 on linseed cake after three days gave trans-(+)-(4S,5R) enantiomer (2a) $(19 \%$, ee $>99 \%)$ and enantiomerically enriched cis-(+)-(4R,5R) whisky lactone $(\mathbf{2 d})(83 \%, e e=93 \%)$. In the biotransformations with G. bronchialis PCM2167, it was observed that from days 3 to 7 , the enantiomeric excess of cis-(+)-(4R,5R) (2d) isomer decreased from $e e=93 \%$ to $85 \%$.

Table 2. Comparison of microbial oxidation of syn-3-methyl-octane-1,4-diol (1b) on linseed and rapeseed cake (in \% according to GC).

\begin{tabular}{|c|c|c|c|c|c|c|c|}
\hline \multirow[b]{2}{*}{ Strain } & \multirow[b]{2}{*}{ Oil Cake } & \multirow{2}{*}{$\begin{array}{l}\text { Time } \\
\text { [days] }\end{array}$} & \multirow{2}{*}{$\begin{array}{c}\text { Conv. 1b } \\
{[\%]}\end{array}$} & \multicolumn{4}{|c|}{ Products } \\
\hline & & & & $\begin{array}{c}\text { Trans 2a-b } \\
{[\%]}\end{array}$ & $\begin{array}{c}e e \\
{[\%]}\end{array}$ & $\begin{array}{c}\text { Cis 2c-d } \\
{[\%]}\end{array}$ & $\begin{array}{c}e e \\
{[\%]}\end{array}$ \\
\hline \multirow{4}{*}{$\begin{array}{l}\text { Gordonia } \\
\text { bronchialis } \\
\text { PCM2167 }\end{array}$} & \multirow{2}{*}{ linseed } & 3 & 100 & $19( \pm 0.7)$ & $>99(+)-(4 S, 5 R)-\mathbf{2 a}$ & $81( \pm 0.7)$ & $93(+)-(4 R, 5 R)-2 d$ \\
\hline & & 7 & 100 & $21( \pm 1.3)$ & $>99(+)-(4 S, 5 R)-\mathbf{2 a}$ & $79( \pm 1.7)$ & $85(+)-(4 R, 5 R)-2 \mathrm{~d}$ \\
\hline & \multirow{2}{*}{ rapeseed } & 3 & 0 & 0 & 0 & 0 & 0 \\
\hline & & 7 & $12( \pm 0.9)$ & 10 & 0 & $2( \pm 0.4)$ & $82(+)-(4 R, 5 R)-2 d$ \\
\hline \multirow{4}{*}{$\begin{array}{l}\text { Rhodococcus } \\
\text { erythropolis } \\
\text { DSM44534 }\end{array}$} & \multirow[b]{2}{*}{ linseed } & 3 & 100 & $27( \pm 0.9)$ & $37(+)-(4 S, 5 R)-\mathbf{2} \mathbf{a}$ & $73( \pm 1.0)$ & $83(+)-(4 R, 5 R)-2 \mathbf{d}$ \\
\hline & & 7 & 100 & $23( \pm 0.6)$ & $78(+)-(4 S, 5 R)-\mathbf{2 a}$ & $77( \pm 1.1)$ & $86(+)-(4 R, 5 R)-2 \mathrm{~d}$ \\
\hline & \multirow{2}{*}{ rapeseed } & 3 & $18( \pm 0.7)$ & $4( \pm 0.1)$ & 0 & $14( \pm 0.3)$ & 0 \\
\hline & & 7 & $57( \pm 1.5)$ & $9( \pm 0.3)$ & 0 & $48( \pm 1.6)$ & $4(+)-(4 R, 5 R)-2 \mathbf{d}$ \\
\hline \multirow{4}{*}{$\begin{array}{c}\text { Rhodococcus } \\
\text { rhodochrous } \\
\text { PCM909 }\end{array}$} & \multirow[b]{2}{*}{ linseed } & 3 & 100 & $25( \pm 0.9)$ & $>99(+)-(4 S, 5 R)-\mathbf{2 a}$ & $75( \pm 1.2)$ & $65(+)-(4 R, 5 R)-2 d$ \\
\hline & & 7 & 100 & $31( \pm 0.4)$ & $>99(+)-(4 S, 5 R)-\mathbf{2 a}$ & $69( \pm 0.7)$ & $67(+)-(4 R, 5 R)-2 \mathrm{~d}$ \\
\hline & \multirow{2}{*}{ rapeseed } & 3 & 0 & 0 & 0 & 0 & 0 \\
\hline & & 7 & 0 & 0 & 0 & 0 & 0 \\
\hline \multirow{4}{*}{$\begin{array}{c}\text { Rhodococcus } \\
\text { ruber } \\
\text { PCM2166 }\end{array}$} & \multirow{2}{*}{ linseed } & 3 & 100 & $37( \pm 0.9)$ & $>99(+)-(4 S, 5 R)-\mathbf{2 a}$ & $63( \pm 1.6)$ & $79(+)-(4 R, 5 R)-2 d$ \\
\hline & & 7 & 100 & $37( \pm 1.2)$ & $>99(+)-(4 S, 5 R)-\mathbf{2 a}$ & $63( \pm 0.8)$ & $83(+)-(4 R, 5 R)-2 \mathbf{d}$ \\
\hline & \multirow{2}{*}{ rapeseed } & 3 & 0 & 0 & 0 & 0 & 0 \\
\hline & & 7 & $22( \pm 0.7)$ & $6( \pm 0.3)$ & 0 & $16( \pm 0.9)$ & 0 \\
\hline
\end{tabular}

On the rapeseed cake, the low conversion of diol and only small amounts of both trans- and cis-whisky lactone isomers were observed. The highest conversion of syn-3methyl-octane-1,4-diol (1b) was observed on rapeseed cake with R. erythropolis DSM44534. There was no conversion in transformation with $R$. rhodochrous PCM909 on rapeseed cake, likewise in oxidation with anti-3-methyl-octane-1,4-diol (1a). In biotransformations on primrose oilcake, no conversion of syn-3-methyl-octane-1,4-diol (1) $)$, similar to that of anti-3-methyl-octane-1,4-diol (1a), was detected.

In biotransformations performed on the linseed cake with G. bronchialis PCM2167, R. ruber PCM2166, R. erythropolis DSM44534 and R. rhodochrous PCM909 (2.1 and 2.2), significantly more trans whisky lactone (81-97\%) was formed when anti-3-methyl-octane1,4-diol (1a) was used as a substrate (Table 1). On the other hand, when syn-3-methyloctane-1,4-diol (1b) was applied, cis-isomer (63-81\%) was formed predominantly (Table 2). Among tested microorganisms it was noticed that in transformations with R. ruber PCM2166 on rapeseed cake, higher conversion (84\%) was obtained with 1a compared to $1 \mathbf{b}(22 \%)$."

According to our previous results [31], trans-(+)-(4S,5R) (2a) and cis-(-)-(4S,5S) (2c) enantiomers of whisky lactones were produced as a result of microbial whole-cell lactonization of the corresponding $\gamma$-oxoacids. The opposite enantiomerically enriched trans-(-)$(4 R, 5 S) \mathbf{( 2 \mathbf { b } )}$ and cis-(+)-(4R,5R) (2d) whisky lactones were obtained in enzymatic oxidation catalyzed by commercially available alcohol dehydrogenases. We developed a SSF oxidation process as an interesting alternative against redox reactions catalyzed by expensive enzymes and required coenzymes. 
There are two possible approaches to obtain chiral lactones from racemic diols [33]. In the first one (Figure 3), the primary hydroxy group of diol is chemoselectively oxidized to a carboxylic group, and then, the corresponding hydroxy carboxylic acid is cyclized to a lactone product. However, in the second pathway, there is a two-step oxidation process. First, diol is oxidized to the corresponding hydroxyaldehyde; then, hemiacetal is formed spontaneously, and it is further oxidized to lactone. Our previous studies, due to isolated hemiacetals, confirmed the second pathway of enzymatic oxidation of diols to whisky lactones. However, in the second pathway, there is a two-step oxidation process. First, diol is oxidized to the corresponding hydroxyaldehyde; then, hemiacetal is formed spontaneously, and it is further oxidized to lactone. Our previous studies, due to isolated hemiacetals, confirmed the second pathway of enzymatic oxidation of diols to whisky lactones [33].

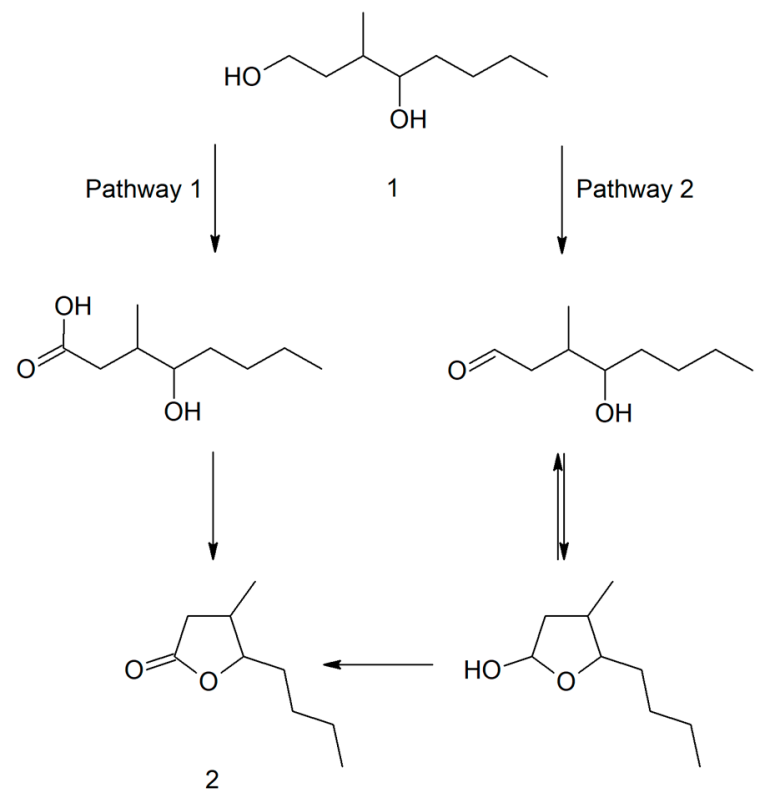

Figure 3. Two possible pathways of biotransformation of 3-methyl-octane-1,4-diol (1).

On the basis of our research, we cannot clearly confirm which of the abovementioned mechanisms takes place during the oxidation catalyzed by bacterial cells. As a result of bacterial oxidation of the diols (1a and $\mathbf{1 b}$ ) in the preliminary screening, we obtained enantiomerically pure or enriched isomers opposite to those isolated in our previous research $[31,33]$. Therefore, further research is required to confirm which path is actually involved in this process because no intermediate products were isolated.

\subsection{Preliminary Screening Scale Biotransformations with a Diastereoisomeric Mixture of Anti- and Syn-3-methyl-octane-1,4-diols (1a-b)}

On the basis of previous screening, only linseed cake was selected for these studies. It is supposed to be related to facts that the linseed cake is characterized by the highest ability to absorb water [37]. In the case of bacteria, it is of great importance because they grow in the entire volume of the substrate, and the even distribution of water throughout the growth medium also causes even bacterial growth. In the case of evening primrose cake, only a part of the water is absorbed, and the rest is on the surface of the substrate, which can reduce bacterial growth. In addition, evening primrose oilcake contains much more fiber, which can slow down the growth of bacteria because it makes them less accessible to nutrients [38]. Rapeseed cake contains sinapic acid, which has antimicrobial activity therefore probably causes worse bacterial growth on this byproduct [39].

Biotransformations with all tested strains with a diastereoisomeric mixture of antiand syn-3-methyl-octane-1,4-diols $(\mathbf{1} \mathbf{a}-\mathbf{b})$ were performed to determine how the mixture 
of substrate stereoisomers affects the obtained products concerning the conversion and enantiomeric purity of lactones (Table 3). The results obtained from the oxidation of a mixture of anti- and syn-diols were the resultant of those received in individual biotransformations presented in paragraphs 2.1 and 2.2. In most biotransformations the trans/cis ratio of whisky lactone isomers was in the range of $39-60 \%$ for trans-2a $40-61 \%$ for cis-2d isomer. Among tested strains the ratio of formed trans/cis-whisky lactones differs significantly only in the transformation with Gordonia bronchialis PCM2167 after three days affording $23 \%$ of the trans-isomer $\mathbf{2 a}$ and $77 \%$ of the cis-isomer $\mathbf{2 d}$. However, after seven days it was $45 / 55 \%$, similar ratio to the rest of the biotransformations. The highest enantiomeric excess $(e e=90 \%)$ of cis- $(+)-(4 R, 5 R)$ lactone $(\mathbf{2 d})$ was obtained in the G. bronchialis PCM2167 culture after three days. In all biotransformations the conversion was 100\%. Since a diastereoisomeric mixture of diols was used as a substrate, a significant decrease in the biotransformation enantioselectivity was observed; thus, separate biotransformations with the individual isomers in subsequent studies were subsequently performed.

Table 3. Microbial oxidation of a mixture of anti- and syn-3-methyl-octane-1,4-diols (1a-b) on linseed cake (in \% according to GC).

\begin{tabular}{|c|c|c|c|c|c|c|}
\hline \multirow[b]{2}{*}{ Strain } & \multirow{2}{*}{$\begin{array}{l}\text { Time } \\
\text { [days] }\end{array}$} & \multirow{2}{*}{$\begin{array}{c}\text { Conv. } \\
\text { 1a-1b } \\
{[\%]}\end{array}$} & \multicolumn{4}{|c|}{ Products } \\
\hline & & & $\begin{array}{c}\text { Trans } 2 \mathrm{a}-\mathrm{b} \\
{[\%]}\end{array}$ & $\begin{array}{c}e e \\
(+)-(4 S, 5 R)-2 \mathrm{a}[\%]\end{array}$ & $\begin{array}{c}\text { Cis } 2 \mathrm{c}-\mathrm{d} \\
{[\%]}\end{array}$ & $\begin{array}{c}e e \\
(+)-(4 R, 5 R)-2 \mathrm{~d}[\%]\end{array}$ \\
\hline Gordonia bronchialis & 3 & 100 & $23( \pm 0.9)$ & 55 & $77( \pm 1.2)$ & 90 \\
\hline PCM2167 & 7 & 100 & $45( \pm 0.7)$ & 52 & $55( \pm 0.6)$ & 70 \\
\hline Rhodococcus erythropolis & 3 & 100 & $47( \pm 1.1)$ & 32 & $53( \pm 1.4)$ & 77 \\
\hline DSM 44534 & 7 & 100 & $47( \pm 0.4)$ & 35 & $53( \pm 0.7)$ & 79 \\
\hline Rhodococcus rhodochrous & 3 & 100 & $39( \pm 0.8)$ & 70 & $61( \pm 1.1)$ & 60 \\
\hline PCM909 & 7 & 100 & $47( \pm 1.7)$ & 76 & $53( \pm 1.9)$ & 74 \\
\hline Rhodococcus ruber & 3 & 100 & $58( \pm 1.4)$ & 30 & $42( \pm 1.1)$ & 32 \\
\hline PCM2166 & 7 & 100 & $60( \pm 1.7)$ & 37 & $40( \pm 0.3)$ & 35 \\
\hline
\end{tabular}

\subsection{Screening Scale Biotransformations with Anti-3-methyl-octane-1,4-diol (1a) on Linseed Cake}

During the first round of biotransformations performed on three different oil cakes, only decent amounts of optically pure isomers of whisky lactones were obtained. Therefore, further screening studies were conducted to select bacteria with significant dehydrogenase activity that effectively catalyze the oxidation of diols to lactones. Based on previous experiments, linseed cake was selected as the growth medium for biotransformation. Next, several strains of bacteria from the Gordonia, Rhodococcus, Micrococcus, Dietzia and Streptomyces species were selected to test their oxidation activity (Table 4).

In transformations carried out with Gordonia rubripertincta PCM2144, Rhodococcus erythropolis PCM2150, Rhodococcus coprophilus PCM2174, Dietzia sp. DSM44016 and Streptomyces griseus subsp. griseus PCM2331, after three days, trans-whisky lactones in amounts ranging from $78 \%$ to $100 \%$ were produced. The highest enantiomeric excess of trans-(+)$(4 S, 5 R)$ isomer $2 \mathbf{a}(e e=78 \%)$ was detected on the 3rd day of transformations with G. rubripertincta PCM2144. As a result of oxidation, the cis-isomer was obtained with the strains $R$. erythropolis PCM2150, R. coprophilus PCM2174, Dietzia sp. DSM44016 and S. griseus subsp. griseus PCM2331. The enantiomerically pure cis-(-)-(4S,5S) whisky lactone (2c) $(e e>99 \%)$ was obtained in the culture of R. erythropolis PCM2150.

By comparing the same genus of bacteria (G. bronchialis PCM2167 vs G. rubripertincta PCM2144, R. erythropolis DSM44534 vs R. erythropolis PCM2150, R. ruber PCM2171 vs $R$. ruber PCM2216) used in both screening experiments (Tables 2 and 4), there is a similarity in the biotransformations carried out by the strains of the same type. 
Table 4. Microbial oxidation of anti-3-methyl-octane-1,4-diol (1a) on linseed cake (in \% according to GC).

\begin{tabular}{|c|c|c|c|c|c|c|}
\hline \multirow[b]{2}{*}{ Strain } & \multirow{2}{*}{$\begin{array}{c}\text { Time } \\
\text { [days] }\end{array}$} & \multirow{2}{*}{$\begin{array}{c}\text { Conv. 1a } \\
{[\%]}\end{array}$} & \multicolumn{4}{|c|}{ Products } \\
\hline & & & $\begin{array}{c}\text { Trans 2a-b } \\
{[\%]}\end{array}$ & $\begin{array}{c}e e \\
{[\%]}\end{array}$ & $\begin{array}{c}\text { Cis } 2 \mathrm{c}-\mathrm{d} \\
{[\%]}\end{array}$ & $\begin{array}{c}e e \\
{[\%]}\end{array}$ \\
\hline Dietzia sp. & 3 & 100 & $80( \pm 1.1)$ & $31(-)-(4 R, 5 S)-\mathbf{2} \mathbf{b}$ & $20( \pm 0.6)$ & $84(+)-(4 R, 5 R)-2 d$ \\
\hline DSM44016 & 7 & 100 & $82( \pm 0.8)$ & $44(-)-(4 R, 5 S)-\mathbf{2 b}$ & $18( \pm 0.7)$ & $85(+)-(4 R, 5 R)-2 \mathrm{~d}$ \\
\hline Gordonia rubripertincta & 3 & 100 & 100 & $78(+)-(4 S, 5 R)-2 \mathbf{a}$ & 0 & 0 \\
\hline PCM2144 & 7 & 100 & 100 & $62(+)-(4 S, 5 R)-2 \mathbf{a}$ & 0 & 0 \\
\hline Micrococcus luteus & 3 & $20( \pm 0.5)$ & $20( \pm 0.7)$ & $12(+)-(4 S, 5 R)-2 \mathbf{a}$ & 0 & 0 \\
\hline PCM525 & 7 & $25( \pm 0.9)$ & $25( \pm 0.2)$ & $15(+)-(4 S, 5 R)-\mathbf{2 a}$ & 0 & 0 \\
\hline Rhodococcus coprophilus & 3 & 100 & $95( \pm 0.6)$ & $7(+)-(4 S, 5 R)-\mathbf{2 a}$ & $5( \pm 0.1)$ & $20(+)-(4 R, 5 R)-2 \mathrm{~d}$ \\
\hline PCM2174 & 7 & 100 & $93( \pm 0.5)$ & $3(+)-(4 S, 5 R)-\mathbf{2 a}$ & $7( \pm 0.7)$ & $30(+)-(4 R, 5 R)-2 \mathrm{~d}$ \\
\hline Rhodococcus erythropolis & 3 & 100 & $80( \pm 1.1)$ & 0 & $20( \pm 0.9)$ & $99(-)-(4 S, 5 S)-2 \mathrm{c}$ \\
\hline PCM2150 & 7 & 100 & $82( \pm 0.8)$ & $27(+)-(4 S, 5 R)-\mathbf{2 a}$ & $18( \pm 0.7)$ & $50(-)-(4 S, 5 S)-2 \mathrm{c}$ \\
\hline Rhodococcus ruber & 3 & $30( \pm 0.2)$ & $30( \pm 0.6)$ & $30(+)-(4 S, 5 R)-2 \mathbf{a}$ & 0 & 0 \\
\hline PCM2171 & 7 & $80( \pm 1.1)$ & $80( \pm 1.5)$ & $9(+)-(4 S, 5 R)-2 \mathbf{a}$ & 0 & 0 \\
\hline Rhodococcus ruber & 3 & 0 & 0 & 0 & 0 & 0 \\
\hline PCM2216 & 7 & $35( \pm 0.9)$ & $35( \pm 0.3)$ & $10(+)-(4 S, 5 R)-\mathbf{2 a}$ & 0 & 0 \\
\hline Streptomyces griseus subsp. griseus & 3 & 100 & $78( \pm 1.5)$ & $50(+)-(4 S, 5 R)-2 \mathbf{a}$ & $22( \pm 0.7)$ & $8(+)-(4 R, 5 R)-2 \mathrm{~d}$ \\
\hline PCM2331 & 7 & 100 & $85( \pm 1.2)$ & $50(+)-(4 S, 5 R)-2 \mathbf{a}$ & $15( \pm 0.4)$ & $25(+)-(4 R, 5 R)-2 \mathrm{~d}$ \\
\hline
\end{tabular}

\subsection{Screening Scale Biotransformations with Syn-3-methyl-octane-1,4-diol (1b) on Linseed Cake}

Analysis of the oxidation performed with G. rubripertincta PCM2144, R. erythropolis PCM2150, R. coprophilus PCM2174 and Dietzia sp. DSM44016 showed 100\% conversion of substrate after three days. During oxidation with most of the strains, enantiomerically enriched cis-(+)-(4R,5R) whisky lactone was obtained (Table 5). The highest amounts from $77 \%$ to $100 \%$ of this isomer were obtained when G. rubripertincta PCM2144, R. erythropolis PCM2150, R. coprophilus PCM2174 and Dietzia sp. DSM44016 were used as the biocatalyst. In the oxidation with Dietzia sp. DSM44016 cis-(+)-(4R,5R) isomer was obtained on the 7 th day $(77 \%$, ee $=79 \%)$. As a result of transformation, an optically active trans-isomer (ee $=50-77 \%)$ was obtained with G. rubripertincta PCM2144, R. coprophilus PCM2174 and Dietzia sp. DSM44016. Biotransformations with S. griseus subsp. griseus PCM2331 showed low conversion with a solely small amounts of trans- and cis-isomers (5-16\%).

Table 5. Microbial oxidation of syn-3-methyl-octane-1,4-diol (1b) on linseed cake (in \% according to GC).

\begin{tabular}{|c|c|c|c|c|c|c|}
\hline \multirow{2}{*}{ Strain } & \multirow{2}{*}{$\begin{array}{l}\text { Time } \\
\text { [days] }\end{array}$} & \multirow{2}{*}{$\begin{array}{c}\text { Conv. } 1 \mathrm{~b} \\
{[\%]}\end{array}$} & \multicolumn{4}{|c|}{ Products } \\
\hline & & & $\begin{array}{c}\text { Trans 2a-b } \\
{[\%]}\end{array}$ & $\begin{array}{c}e e \\
{[\%]}\end{array}$ & $\begin{array}{c}\text { Cis } 2 \mathrm{c}-\mathrm{d} \\
{[\%]}\end{array}$ & $\begin{array}{c}e e \\
{[\%]}\end{array}$ \\
\hline Dietzia sp. & 3 & 100 & $27( \pm 0.7)$ & $77(+)-(4 S, 5 R)-\mathbf{2 a}$ & $73( \pm 1.2)$ & $75(+)-(4 R, 5 R)-2 d$ \\
\hline DSM44016 & 7 & 100 & $23( \pm 0.9)$ & $50(+)-(4 S, 5 R)-2 \mathbf{a}$ & $77( \pm 0.4)$ & $79(+)-(4 R, 5 R)-2 \mathrm{~d}$ \\
\hline Gordonia rubripertincta & 3 & 100 & $40( \pm 0.3)$ & $77(+)-(4 S, 5 R)-\mathbf{2 a}$ & $60( \pm 1.2)$ & $32(-)-(4 S, 5 S)-2 \mathrm{c}$ \\
\hline PCM2144 & 7 & 100 & $16( \pm 0.5)$ & $62(+)-(4 S, 5 R)-2 \mathbf{a}$ & $84( \pm 2.1)$ & $30(-)-(4 S, 5 S)-2 c$ \\
\hline Micrococcus luteus & 3 & $30( \pm 0.4)$ & 0 & 0 & $30( \pm 0.9)$ & $20(+)-(4 R, 5 R)-2 \mathrm{~d}$ \\
\hline PCM525 & 7 & $35( \pm 1.3)$ & 0 & 0 & $35( \pm 1.1)$ & $29(+)-(4 R, 5 R)-2 \mathrm{~d}$ \\
\hline Rhodococcus coprophilus & 3 & 100 & $15( \pm 0.4)$ & $60(+)-(4 S, 5 R)-2 \mathbf{a}$ & $85( \pm 1.2)$ & $33(+)-(4 R, 5 R)-2 \mathrm{~d}$ \\
\hline PCM2174 & 7 & 100 & $30( \pm 0.9)$ & $75(+)-(4 S, 5 R)-\mathbf{2 a}$ & $70( \pm 0.7)$ & $33(+)-(4 R, 5 R)-2 \mathrm{~d}$ \\
\hline Rhodococcus erythropolis & 3 & 100 & 0 & 0 & 100 & $5(+)-(4 R, 5 R)-2 d$ \\
\hline PCM2150 & 7 & 100 & 0 & 0 & 100 & $2(+)-(4 R, 5 R)-2 \mathrm{~d}$ \\
\hline Rhodococcus ruber & 3 & $30( \pm 0.2)$ & 0 & 0 & $30( \pm 1.7)$ & $10(-)-(4 S, 5 S)-2 \mathrm{c}$ \\
\hline PCM2171 & 7 & $60( \pm 1.3)$ & 0 & 0 & $60( \pm 1.8)$ & 0 \\
\hline Rhodococcus ruber & 3 & $35( \pm 0.7)$ & 0 & 0 & $35( \pm 1.1)$ & $30(+)-(4 R, 5 R)-2 \mathrm{c}$ \\
\hline PCM2216 & 7 & $35( \pm 0.4)$ & 0 & 0 & $35( \pm 1.3)$ & 0 \\
\hline Streptomyces griseus subsp. griseus & 3 & $10( \pm 0.2)$ & 5 & 0 & $5( \pm 0.3)$ & $60(+)-(4 R, 5 R)-2 \mathrm{~d}$ \\
\hline PCM2331 & 7 & $27( \pm 1.2)$ & 16 & 0 & $11( \pm 0.3)$ & $60(+)-(4 R, 5 R)-2 \mathrm{~d}$ \\
\hline
\end{tabular}


Comparing the same bacteria from Gordonia genus only with G. bronchialis PCM2167, enantiomerically pure trans-whisky lactone was formed (Table 2). R. erythropolis PCM2150 (Table 5) transformed diol (1b) to cis-whisky lactone with lower enantiomeric excess than R. erythropolis DSM44534 (Table 2), and no trans-isomer was formed. R. ruber PCM2166 (Table 2) oxidized diol (1b) with higher conversion and enantioselectivity than $R$. ruber PCM2171 and R. ruber PCM2216 (Table 5).

During biotransformation of anti- and syn-diols with strains Dietzia maris PCM2292 and Rhodococcus rhodnii PCM2157 (not mentioned in Tables 4 and 5), there was no conversion, which proves that these bacteria do not have the ability to oxidize 3-methyl-octane-1,4-diol on linseed cake. Biotransformations with Micrococcus luteus PCM525 and Rhodococcus ruber PCM2216 showed low conversion (20-35\%). With anti-diol (1a), only a small amount of trans-isomer (20-35\%) was formed, and with syn-diol (1b) only cis-isomer of whisky lactone was produced $(30-35 \%)$.

In bioxidation carried out with the following strains Dietzia sp. DSM44016, G. rubripertincta PCM2144, R. coprophilus PCM2174, R. erythropolis PCM2150, R. ruber PCM2171, and S. griseus subsp. griseus PCM2331 (Tables 4 and 5), it was also noticed that more trans-whisky lactone was produced after seven days (80-100\%) when the anti-diol (1a) was used as the substrate. However, when syn-diol (1b) was added, more cis-whisky lactone isomer was formed predominantly after seven days $(60-100 \%)$ within the same strains, except for S. griseus subsp. griseus PCM2331 (5-11\%). We identified three biocatalysts M. luteus PCM525, R. ruber PCM2171, R. ruber PCM2216, which catalyzed highly diastereoselective oxidation independently of the substrate used, affording only trans-whisky isomers from anti-diol and cis-whisky isomers from syn-diol. Application of two stereochemically different substrates in biotransformations catalyzed by G. rubripertincta PCM2144 and R. erythropolis PCM2150 was significant concerning diastereoselectivity of the process. In oxidation catalyzed by G. rubripertincta PCM2144 using anti-diol only trans-isomer was obtained, however with syn-diol a mixture of cis/trans-isomers was observed. In contrary, R. erythropolis PCM2150 catalyzed oxidation of syn-diol to only cis-lactone, while from anti-diol a mixture of cis/trans-whisky isomers was detected.

\subsection{Selection of the Extraction Method}

On the basis of screening studies, a simple extraction method using organic solvents was applied to isolate biotransformation products on a preparative scale. While conducting simple extraction in preparative biotransformations, a problem arose related to the extraction of excessive amounts of fat from linseed cake. Attempts to separate the lipid fraction via column chromatography were unsuccessful; the columns clogged, and only $10-15 \%$ of the product was obtained. Therefore, it was decided to test other extraction methods. Extraction with the Deryng apparatus was then tested, but the cake foamed and burned easily when the flask was heated (even at low heating temperatures). In next method steam distillation was tested. The efficiency during steam distillation was $85 \%$; however, due to the high content of protein in the cake, it foamed considerably. Therefore, the extraction process had to be performed several times because the resulting foam filled the entire distillation flask, which significantly extended the time of this method. Taking into consideration this fact, it was decided to conduct steam distillation from organic extract first to obtain a simple extraction of the preparative biotransformation. The yield of this method was $81 \%$, and distillation could be performed in one step due to the volume of the obtained extract was small and did not foam. This method turned out to be the most effective among all tested and was used in all preparative biotransformations.

\subsection{Calibration of Moisture Sensor}

To control humidity during biotransformation in the bioreactor, two types of electrodes were tested. First, measurements were carried out with graphite electrodes and then with a probe for measuring soil moisture (Waveshare 9527) on linseed and rapeseed cake. Based on measurements conducted with graphite electrodes, a correlation graph of moisture and 
voltage in rapeseed cakes was created (Figure 4a). The lowest value of moisture was $15 \%$ for rapeseed cake. With moisture lower than $15 \%$, the sensor could not detect voltage. The voltage increased for a moisture from 15 to $90 \%$. Figure $4 \mathrm{~b}$ shows that for linseed cake, the lowest value of moisture conducted with graphite electrodes, which could be marked, was $20 \%$. Voltage increased for the moisture from 20 to $90 \%$. A steady increase in voltage was observed for moisture in the range from 40 to $50 \%$. The smallest increase in voltage was observed from 60 to $70 \%$ moisture, and the largest increase was from 30 to $60 \%$ moisture.

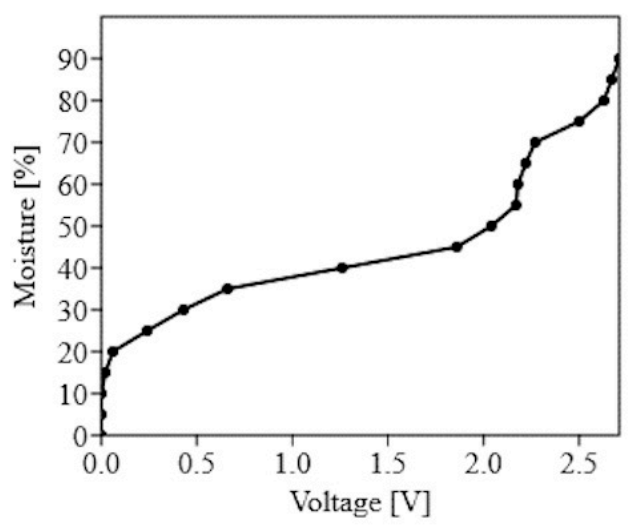

(a)

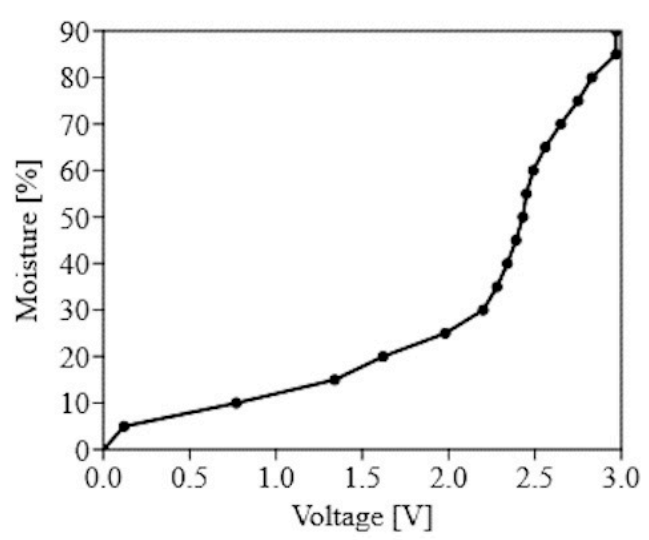

(c)

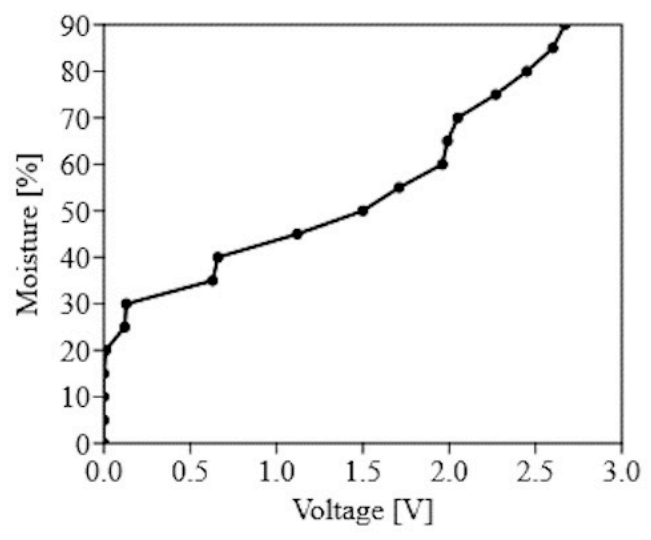

(b)

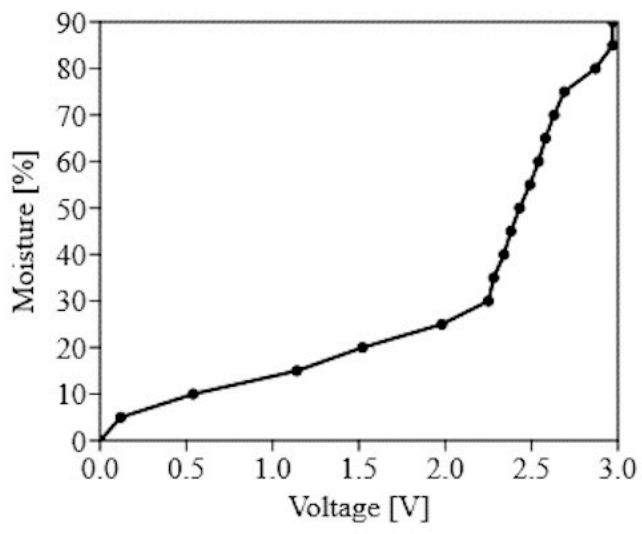

(d)

Figure 4. Correlation curves of moisture and voltage: (a) measured with graphite electrodes for rapeseed cake; (b) measured with graphite electrodes for linseed cake; (c) measured with probe (Waveshare 9527) for rapeseed cake; (d) measured with probe (Waveshare 9527) for linseed cake.

When measuring the moisture in the rapeseed cake with a probe (Waveshare 9527), the first measurable voltage reading was $5 \%$ medium moisture (Figure $4 \mathrm{c}$ ). The maximum reading range ended at $85 \%$ medium moisture. In the ranges of $5 \%$ to $30 \%, 30 \%$ to $60 \%$ and $60 \%$ to $80 \%$, the values were similar to linear, allowing humidity control between these values. The first measurement at $5 \%$ humidity was also obtained in the measurement of moisture on the linseed cake using a probe with a humidity sensor (Waveshare 9527). The maximum range also ended at $85 \%$ humidity because the voltage was constant above this value (Figure 4 d). Linear values were obtained in the range from 5 to $30 \%$ and from 30 to $75 \%$ humidity, allowing for the precise control of humidity in the medium.

Comparing the values obtained when controlling the medium with different electrodes, we decided to use a sensor with a probe to measure the humidity. This made it possible to obtain more linear values in wide ranges of humidity, which allowed for 
more accurate measurements. Additionally, this sensor was easier to work with and to keep clean.

\subsection{Preparative Biotransformations with Anti-and Syn-3-methyl-octane-1,4-diols (1a-b)}

A prototype SSF bioreactor was designed and constructed to conduct preparative biotransformations under constant conditions of humidity and oxygenation. During multiple tests of the SSF bioreactor, we confirmed that materials that were used for its design were chosen in an appropriate manner. The cover of the bioreactor (polypropylene), glass capillary, graphite electrodes, probe (Waveshare 9527) and TMP36GT9Z temperature sensor survived multiple sterilization as well as contact with microorganisms and organic solvents. All the elements of the bioreactor were easy to clean and maintain. In the case of damage, electrodes or capillaries can be quickly and simply replaced with new electrodes or capillaries. The air pump that we used in bioreactor ensures good gas exchange.

In preparative biotransformations, bacterial cultures with $\mathrm{OD}_{600}=0.3$ were added to the oilcakes. It was observed that the growth of bacteria was associated with the production of metabolites causing sludge formation and a slight discoloration of the medium. During preliminary studies on preparative scale, it was noticed that the addition of substrate before 4 th day after bacterial inoculation led to lower conversion and enantioselectivity of the biotransformation.

On the basis of previous screening experiments for preparative biotransformations of diols (1a-b), the following strains were selected: Rhodococcus erythropolis DSM44534, $R$. erythropolis PCM2150 and Gordonia rubripertincta PCM2144. Biotransformations of syn-3methyl-octane-1,4-diol (1b) catalyzed by R. erythropolis DSM44534 and G. rubripertincta PCM2144 showed 80-100\% conversion of the substrate after seven days (Table 6). The isolation yield of a mixture of optically active trans-(+)-(4S,5R) (2a) and cis-(+)-(4R,5R) (2d) whisky lactone isomers in the transformation with $R$. erythropolis DSM44534 was 79.4\%. Specific rotations of the enantiomerically enriched trans- $(+)-(4 S, 5 R)(2 \mathbf{a})\left([\alpha]_{\mathrm{D}}^{20}=+79.7(\mathrm{c}=0.25\right.$, $\mathrm{CH}_{3} \mathrm{OH}, e e=80 \%$, yield $\left.=17.4 \%\right)$; ref. $[\alpha]_{\mathrm{D}}^{20}=+97.0\left(\mathrm{c}=0.34, \mathrm{CH}_{3} \mathrm{OH}\right.$, ee $\left.\left.=99 \%\right)[40]\right)$ and cis- $(+)-(4 R, 5 R)(2 \mathrm{~d})\left([\alpha]_{\mathrm{D}}^{20}=+52.1\left(\mathrm{c}=0.2, \mathrm{CH}_{3} \mathrm{OH}, e e=66 \%\right.\right.$, yield $\left.=62 \%\right) ;$ ref. $[\alpha]_{\mathrm{D}}^{20}=+79.0$ (c $=0.5, \mathrm{CH}_{3} \mathrm{OH}, e e=99 \%$ ) [40]) whisky lactones were measured and compared with data from the literature. The biotransformation with G. rubripertincta PCM2144 was highly selective and afforded only enantiomerically enriched trans-(+)-(4S,5R)-isomer $(2 \mathbf{a})\left([\alpha]_{\mathrm{D}}^{20}=+61.2\right.$ $\left(\mathrm{c}=0.15, \mathrm{CH}_{3} \mathrm{OH}, e e=66 \%\right.$ ) with an isolation yield $=68 \%$.

Table 6. Comparison of microbial oxidation of syn-3-methyl-octane-1,4-diol (1b) on linseed cake (in \% according to GC).

\begin{tabular}{|c|c|c|c|c|c|c|}
\hline \multirow[b]{2}{*}{ Strain } & \multirow{2}{*}{$\begin{array}{l}\text { Time } \\
\text { [days] }\end{array}$} & \multirow{2}{*}{$\begin{array}{c}\text { Conv. 1b } \\
{[\%]}\end{array}$} & \multicolumn{4}{|c|}{ Products } \\
\hline & & & $\begin{array}{c}\text { Trans 2a } \\
{[\%]}\end{array}$ & $\begin{array}{c}e e \\
{[\%]}\end{array}$ & $\begin{array}{c}\text { Cis } 2 \mathrm{~d} \\
{[\%]}\end{array}$ & $\begin{array}{c}e e \\
{[\%]}\end{array}$ \\
\hline Gordonia rubripertincta & 4 & $25( \pm 0.6)$ & $25( \pm 0.9)$ & $55(+)-(4 S, 5 R)-\mathbf{2 a}$ & 0 & 0 \\
\hline PCM 2144 & 7 & 100 & 100 & $66(+)-(4 S, 5 R)-\mathbf{2} \mathbf{a}$ & 0 & 0 \\
\hline Rhodococcus erythropolis & 4 & $15( \pm 0.3)$ & $3( \pm 0.2)$ & $65(+)-(4 S, 5 R)-2 \mathbf{a}$ & $12( \pm 0.5)$ & $54(+)-(4 R, 5 R)-2 d$ \\
\hline DSM44534 & 7 & $80( \pm 1.2)$ & $22( \pm 0.6)$ & $80(+)-(4 S, 5 R)-2 \mathbf{a}$ & $58( \pm 0.5)$ & $66(+)-(4 R, 5 R)-2 \mathrm{~d}$ \\
\hline
\end{tabular}

Analysis of the oxidation of anti-3-methyl-octane-1,4-diol (1a) with G. rubripertincta PCM2144 and R. erythropolis PCM2150 showed 90-100\% conversion of the substrate after seven days (Table 7). In both biotransformations, a mixture of enantiomerically enriched trans-(+)-(4S,5R) (2a) and cis-(-)-(4S,5S) (2c) whisky lactones was obtained. It is worth emphasizing that in the biotransformation of substrate $\mathbf{1 a}$, opposite to the oxidation of $\mathbf{1 b}$, the optically active cis-(-)-(4S,5S) isomer (2c) of whisky lactone was produced. The overall isolation yields of the biotransformations catalyzed by G. rubripertincta PCM2144 and R. erythropolis PCM2150 were 65\% and 61\%, respectively. In the transformation with $R$. erythropolis PCM2150, enantiomerically enriched trans- $(+)-(4 S, 5 R)(\mathbf{2 a})\left([\alpha]_{\mathrm{D}}^{20}=+32.8(\mathrm{c}=0.1\right.$, 
$\mathrm{CH}_{3} \mathrm{OH}, e e=35 \%$, yield $\left.=45 \%\right)$ and cis- $(-)-(4 S, 5 S)(2 \mathrm{c})\left([\alpha]_{\mathrm{D}}^{20}=-54.5\left(\mathrm{c}=0.1, \mathrm{CH}_{3} \mathrm{OH}\right.\right.$, $e e=66 \%$, yield $=14 \%)$; ref. $\left.[\alpha]_{\mathrm{D}}^{20}=-79.0\left(\mathrm{c}=0.5, \mathrm{CH}_{3} \mathrm{OH}, e e=99 \%\right)[40]\right)$, whisky lactones were isolated. Preparative oxidation catalyzed by G. rubripertincta PCM2144 delivered enantiomerically enriched trans-(+)-(4S,5R)-isomer $(2 \mathbf{a})\left([\alpha]_{\mathrm{D}}^{20}=+60.7\left(\mathrm{c}=0.086, \mathrm{CH}_{3} \mathrm{OH}\right.\right.$, $e e=64 \%$, yield $=15.1 \%)$ and cis- $(-)-(4 S, 5 S)$-isomer $(2 \mathrm{c})\left([\alpha]_{\mathrm{D}}^{20}=-24.3\left(\mathrm{c}=0.1, \mathrm{CH}_{3} \mathrm{OH}\right.\right.$, $e e=25 \%$, yield $=42 \%$ ) of whisky lactones.

Table 7. Comparison of microbial oxidation of anti-3-methyl-octane-1,4-diol (1a) on linseed cake (in \% according to GC).

\begin{tabular}{|c|c|c|c|c|c|c|}
\hline \multirow[b]{2}{*}{ Strain } & \multirow{2}{*}{$\begin{array}{c}\text { Time } \\
\text { [days] }\end{array}$} & \multirow{2}{*}{$\begin{array}{c}\text { Conv. 1a } \\
{[\%]}\end{array}$} & \multicolumn{4}{|c|}{ Products } \\
\hline & & & $\begin{array}{c}\text { Trans 2a } \\
{[\%]}\end{array}$ & $\begin{array}{c}e e \\
{[\%]}\end{array}$ & $\begin{array}{c}\text { Cis 2c } \\
{[\%]}\end{array}$ & $\begin{array}{c}e e \\
{[\%]}\end{array}$ \\
\hline Gordonia rubripertincta & 4 & $54( \pm 1.1)$ & $18( \pm 0.4)$ & $51(+)-(4 S, 5 R)-\mathbf{2 a}$ & $36( \pm 0.9)$ & $27(-)-(4 S, 5 S)-2 \mathrm{c}$ \\
\hline PCM2144 & 7 & $90( \pm 1.5)$ & $21( \pm 0.7)$ & $64(+)-(4 S, 5 R)-\mathbf{2 a}$ & $69( \pm 1.1)$ & $25(-)-(4 S, 5 S)-2 \mathrm{c}$ \\
\hline Rhodococcus erythropolis & 4 & $56( \pm 0.3)$ & $45( \pm 0.2)$ & 0 & $11( \pm 0.4)$ & $68(-)-(4 S, 5 S)-2 c$ \\
\hline PCM 2150 & 7 & 100 & $77( \pm 1.3)$ & $35(+)-(4 S, 5 R)-\mathbf{2 a}$ & $23( \pm 0.8)$ & $66(-)-(4 S, 5 S)-2 \mathrm{c}$ \\
\hline
\end{tabular}

\section{Materials and Methods}

\subsection{Microorganisms}

Micrococcus luteus PCM525, Streptomyces griseus subsp. griseus PCM2331, Dietzia maris PCM2292, Rhodococcus coprophilus PCM2174, Rhodococcus erythropolis PCM2150, Rhodococcus rhodnii PCM2157, Rhodococcus rhodochrous PCM909, Rhodococcus ruber PCM2166, Rhodococcus ruber PCM2171, Rhodococcus ruber PCM2216, Gordonia bronchialis PCM2167, Gordonia rubripertincta PCM2144 came from the Polish Academy of Sciences. Dietzia sp. DSM44016 and Rhodococcus erythropolis DSM44534 came from the Department of Chemistry at Wroclaw University of Environmental and Life Sciences. Biocatalysts were maintained at $4{ }^{\circ} \mathrm{C}$ on PCM agar slants then transferred into conical flasks with PCM medium containing sodium chlorine $(6 \mathrm{~g})$, glucose $(20 \mathrm{~g})$, casein $(2 \mathrm{~g})$, bacteriological peptone $(10 \mathrm{~g})$ and yeast extract $(2 \mathrm{~g})$ dissolved in distilled water $(1 \mathrm{~L})$ at $25^{\circ} \mathrm{C} \mathrm{pH} 5.5$.

\subsection{Materials}

A diastereoisomeric mixture of whisky lactones, $\mathrm{LiAlH}_{4}$ and $\mathrm{PCM}$ medium ingredients were purchased from Sigma-Aldrich Chemical Co., St. Louis, MO, USA. Oilseed cakes were purchased from Oleofarm, Wroclaw, Poland.

\subsection{Measurement of Oilseed Cake Moisture}

Five grams of linseed, rapeseed and primrose cakes were weighed into a roundbottom flask. The outlet of the flasks was clogged with cotton wool, and each sample was weighed on an analytical balance and placed in a freeze dryer. The prepared samples were freeze-dried for $24 \mathrm{~h}$ and then weighed on an analytical balance. For each oilseed cakes, five repetitions were performed.

\subsection{Separation of the cis/trans-Whisky Lactones}

A diastereoisomeric mixture of cis / trans-whisky lactones was separated using column chromatography. For this purpose, a column filled with silica gel dissolved in hexane was prepared, and then, $1.0 \mathrm{~g}$ of the cis/trans-whisky lactone mixture was applied. The column was eluted with a mixture of hexane:ethylacetate:diethylether:methylene chloride in a ratio of 20:1:1:1. Fractions were collected and controlled using gas chromatography (GC) [8]. Finally, trans- $(0.430 \mathrm{~g})$ and cis- $(0.500 \mathrm{~g})$ whisky lactones were collected separately. Spectral data were attached in supporting information (SI).

Trans-whisky lactone ${ }^{1} \mathrm{H}$ NMR $\left(600 \mathrm{MHz}_{2} \mathrm{CDCl}_{3}\right) \delta: 0.91\left(\mathrm{t}, J=7.2 \mathrm{~Hz}, 3 \mathrm{H}, \mathrm{CH}_{3}-4^{\prime}\right) ; 1.13$ $\left(\mathrm{d}, \mathrm{J}=6.5 \mathrm{~Hz}, 3 \mathrm{H}, \mathrm{CH}_{3}-4\right) ; 1.32-1.42\left(\mathrm{~m}, 3 \mathrm{H}, \mathrm{CH}_{2}-3^{\prime}\right.$, one of $\left.\mathrm{CH}_{2}-2^{\prime}\right) ; 1.50(\mathrm{~m}, 1 \mathrm{H}$, one of $\left.\mathrm{CH}_{2}-2^{\prime}\right) ; 1.60\left(\mathrm{~m}, 1 \mathrm{H}\right.$, one of $\left.\mathrm{CH}_{2}-1^{\prime}\right) ; 1.68\left(\mathrm{~m}, 1 \mathrm{H}\right.$, one of $\left.\mathrm{CH}_{2}-1^{\prime}\right) ; 2.15-2.25(\mathrm{~m}, 2 \mathrm{H}$, one of 
$\left.\mathrm{CH}_{2}-3, \mathrm{H}-4\right) ; 2.66\left(\mathrm{~m}, 1 \mathrm{H}\right.$, one of $\left.\mathrm{CH}_{2}-3\right) ; 4.00(\mathrm{td}, J=7.9,4.0 \mathrm{~Hz}, 1 \mathrm{H}, \mathrm{H}-5) ;{ }^{13} \mathrm{C} \mathrm{NMR}$ $\left(150 \mathrm{MHz}, \mathrm{CDCl}_{3}\right)$ : $\delta 13.89\left(\mathrm{C}-4^{\prime}\right), 17.49\left(\mathrm{CH}_{3}-4\right), 22.49\left(\mathrm{C}-3^{\prime}\right), 27.85\left(\mathrm{C}-2^{\prime}\right), 33.70\left(\mathrm{C}-1^{\prime}\right)$, 36.08 (C-4), 37.13 (C-3), 87.46 (C-5), 176.61 (C-2); IR (film, $\mathrm{cm}^{-1}$ ): 1787 (s), 1222 (s), 1187 (s) (Figures S2-S4 SI).

Cis-whisky lactone ${ }^{1} \mathrm{H}$ NMR $\left(600 \mathrm{MHz}_{\mathrm{CDCl}}\right) \delta: 0.91\left(\mathrm{t}, J=7.3 \mathrm{~Hz}, 3 \mathrm{H}, \mathrm{CH}_{3}-4^{\prime}\right) ; 1.00(\mathrm{~d}$, $\left.J=7.0 \mathrm{~Hz}, 3 \mathrm{H}, \mathrm{CH}_{3}-4\right) ; 1.29-1.40\left(\mathrm{~m}, 3 \mathrm{H}, \mathrm{CH}_{2}-3^{\prime}\right.$, one of $\left.\mathrm{CH}_{2}-2^{\prime}\right) ; 1.45-1.54(\mathrm{~m}, 2 \mathrm{H}$, one of $\mathrm{CH}_{2}-2^{\prime}$, one of $\left.\mathrm{CH}_{2}-1^{\prime}\right) ; 1.65\left(\mathrm{~m}, 1 \mathrm{H}\right.$, one of $\left.\mathrm{CH}_{2}-1^{\prime}\right) ; 2.18(\mathrm{dd}, J=17.0,4.0 \mathrm{~Hz}, 1 \mathrm{H}$, one of $\left.\mathrm{CH}_{2}-3\right) ; 2.57$ (m, 1H, H-4); 2.67 (dd, $J=17.0,7.8 \mathrm{~Hz}, 1 \mathrm{H}$, one of $\left.\mathrm{CH}_{2}-3\right) ; 4.42$ (ddd, $J=10.1$, 5.6, 4.1 Hz, 1H, H-5); ${ }^{13} \mathrm{C} \mathrm{NMR}\left(150 \mathrm{MHz}, \mathrm{CDCl}_{3}\right)$ : $\delta 13.82\left(\mathrm{CH}_{3}-4\right), 13.90\left(\mathrm{C}-4^{\prime}\right), 22.51\left(\mathrm{C}-3^{\prime}\right)$, $28.03\left(\mathrm{C}-2^{\prime}\right), 29.57(\mathrm{C}-4), 33.01\left(\mathrm{C}-1^{\prime}\right), 37.56$ (C-3), 83.70 (C-5), $176.94(\mathrm{C}-2)$; IR (film, $\left.\mathrm{cm}^{-1}\right)$ : 1787 (s), 1219 (m), 1180 (s) (Figures S5-S7 SI).

\subsection{Chemical Reduction of Whisky Lactones}

In the round-bottom flask, $0.420 \mathrm{~g}$ of racemic trans-whisky lactone $(\mathbf{2} \mathbf{a}-\mathbf{b})$ dissolved in $50 \mathrm{~mL}$ of diethyl ether was placed, followed by the addition of $0.128 \mathrm{~g} \mathrm{LiAlH}_{4}$. Similarly, $0.480 \mathrm{~g}$ of racemic cis-whisky lactone $(2 \mathrm{c}-\mathrm{d})$ was dissolved in diethyl ether, followed by the addition of $0.146 \mathrm{~g} \mathrm{LiAlH}_{4}$. The flask with the attached condenser was placed on a magnetic stirrer. The reduction was carried out for $24 \mathrm{~h}$ at $20^{\circ} \mathrm{C}$. The reaction was controlled by thin-layer chromatography (TLC) and gas chromatography (GC). After completion of the reaction, $10 \% \mathrm{HCl}$ was added to a mixture to spread the excess $\mathrm{LiAlH}_{4}$. The content of the flask was then transferred to the splitter and extracted three times with diethyl ether. The collected organic layer was then extracted with saturated $\mathrm{NaCl}$ solution and dried with $\mathrm{MgSO}_{4}$, passed through a paper filter and evaporated under reduced pressure. As a result of the reduction, $0.380 \mathrm{~g}$ of anti-3-methyl-octane-1,4-diol (1a) (yield $=90.4 \%$ ) and $0.456 \mathrm{~g}$ of syn-3-methyl-octane-1,4-diol $(\mathbf{1 b})$ (yield = 95\%) were obtained. Spectral data were attached in supporting information (SI).

Anti-3-methyl-octane-1,4-diol (1a) ${ }^{1} \mathrm{H} \mathrm{NMR}\left(600 \mathrm{MHz}, \mathrm{CDCl}_{3}\right) \delta: 0.87(\mathrm{~d}, J=6.8 \mathrm{~Hz}, 3 \mathrm{H}$, $\left.\mathrm{CH}_{3}-3\right) ; 0.89\left(\mathrm{t}, \mathrm{J}=7.1 \mathrm{~Hz}, 3 \mathrm{H}, \mathrm{CH}_{3}-8\right) ; 1.22-1.36\left(\mathrm{~m}, 3 \mathrm{H}\right.$, one of $\left.\mathrm{CH}_{2}-6, \mathrm{CH}_{2}-7\right) ; 1.38-1.46(\mathrm{~m}$, $3 \mathrm{H}, \mathrm{CH}_{2}-5$, one of $\left.\mathrm{CH}_{2}-6\right) ; 1.50\left(\mathrm{~m}, 1 \mathrm{H}\right.$, one of $\left.\mathrm{CH}_{2}-2\right) ; 1.67-1.77\left(\mathrm{~m}, 2 \mathrm{H}\right.$, one of $\left.\mathrm{CH}_{2}-2, \mathrm{H}-3\right)$; 2.81 i 3.00 (two s, 2H, 2xOH); 3.55 (m, 1H, H-4); 3.62 (ddd, $J=10.9,7.1,5.0 \mathrm{~Hz}, 1 \mathrm{H}$, one of $\left.\mathrm{CH}_{2}-1\right) ; 3.73\left(\mathrm{ddd}, \mathrm{J}=10.9,6.4,5.0 \mathrm{~Hz}, 1 \mathrm{H}\right.$, one of $\left.\mathrm{CH}_{2}-1\right) ;{ }^{13} \mathrm{C} \mathrm{NMR}\left(150 \mathrm{MHz}, \mathrm{CDCl}_{3}\right)$ ઈ: $13.89\left(\mathrm{CH}_{3}-3\right), 14.12$ (C-8), 22.79 (C-7), 28.70 (C-6), 33.35 (C-5), 35.99 (C-3), 36.20 (C-2), 60.65 (C-1), 74.97 (C-4); IR (film, cm ${ }^{-1}$ ): 3342 (s), 1475 (m), 1395 (m), 1065 (m), 1018 (m) (Figures S8-S10 SI).

Syn-3-methyl-octane-1,4-diol (1b) ${ }^{1} \mathrm{H} \mathrm{NMR}\left(600 \mathrm{MHz}, \mathrm{CDCl}_{3}\right) \delta: 0,89(\mathrm{t}, J=7.1 \mathrm{~Hz}, 3 \mathrm{H}$, $\left.\mathrm{CH}_{3}-8\right) ; 0.92\left(\mathrm{~d}, \mathrm{~J}=6.8 \mathrm{~Hz}, 3 \mathrm{H}, \mathrm{CH}_{3}-3\right) ; 1.23-1.36\left(\mathrm{~m}, 3 \mathrm{H}\right.$, one of $\left.\mathrm{CH}_{2}-6, \mathrm{CH}_{2}-7\right) ; 1.37-1.51(\mathrm{~m}$, $3 \mathrm{H}, \mathrm{CH}_{2}-5$, one of $\left.\mathrm{CH}_{2}-6\right) ; 1.56\left(\mathrm{~m}, 1 \mathrm{H}\right.$, one of $\left.\mathrm{CH}_{2}-2\right) ; 1.62-1.70\left(\mathrm{~m}, 2 \mathrm{H}\right.$, one of $\mathrm{CH}_{2}-2$, H-3);3.13 (s, 2H, 2xOH); 3.38 (ddd, $J=8.4,5.5,3.3 \mathrm{~Hz}, 1 \mathrm{H}, \mathrm{H}-4)$; 3.59 (ddd, $J=11.4,6.9$, $5.1 \mathrm{~Hz}, 1 \mathrm{H}$, one of $\left.\mathrm{CH}_{2}-1\right)$; $3.72\left(\mathrm{ddd}, J=11.4,6.7,5.0 \mathrm{~Hz}, 1 \mathrm{H}\right.$, one of $\left.\mathrm{CH}_{2}-1\right)$; ${ }^{13} \mathrm{C}$ NMR $\left(150 \mathrm{MHz}, \mathrm{CDCl}_{3}\right)$ \&: 14.12 (C-8), 16.60 (CH3-3), 22.81 (C-7), 28.06 (C-6), 34.14 (C-5), 35.26 (C2), 36.43 (C-3), 60.31 (C-1), 75.82 (C-4); IR (film, $\mathrm{cm}^{-1}$ ): 3333 (s), 1480 (s), 1386 (s),1069 (s), 1018 (s) (Figures S11-S13 SI).

\subsection{Screening Scale Biotransformations}

Five grams of oilseed cake (linseed, rapeseed or primrose) was weighed into $100 \mathrm{~mL}$ tapered flasks and then sterilized at $121{ }^{\circ} \mathrm{C}$ at a pressure of $1 \mathrm{~atm}$. The medium was inoculated with $0.5 \mathrm{~mL}$ of preprepared cultures of bacteria at $\mathrm{OD}_{600}=0.3$. The prepared bacterial cultures were placed for 4 days at $30{ }^{\circ} \mathrm{C}$. After this time, $0.01 \mathrm{~g}$ of the substrate (anti-3-methyl-octane-1,4-diol (1a) or syn-3-methyl-octane-1,4-diol (1b)) dissolved in $0.5 \mathrm{~mL}$ of acetone and $0.5 \mathrm{~mL}$ of water was sprayed onto each of the flasks. For simple extraction, ethyl acetate $(25 \mathrm{~mL})$ was added to the samples and shaken for $5 \mathrm{~min}$ at $200 \mathrm{rpm}$ in Falcon tubes. The organic phase was transferred to a vial and dehydrated by anhydrous $\mathrm{MgSO}_{4}$. Then, it was filtered through a paper filter to a GC vial. Biotransformation was controlled after three and seven days on the GC. Control experiments were also performed in which 
microorganisms were cultured on the medium without the addition of substrate to check their metabolites. The stability of the substrate was also checked by the addition of the substrate to the medium without microorganisms.

\subsection{Statystical Analysis}

All the described experiments were performed in triplicate, and the values presented in the tables are the mean of the obtained results. Student's $t$-test showed that all the data did not differ significantly. Additionally, the values of the standard deviation were calculated for the conversion and a percentage of whisky lactone isomers are shown in the tables. Statistical analyses were performed by Past 4.02 .

\subsection{Preparative Biotransformations}

Linseed cake (50 g) was placed in the bioreactor vessel. The bioreactor was sterilized at $121{ }^{\circ} \mathrm{C}$ for $15 \mathrm{~min}$. Subsequently, the medium was inoculated with $5 \mathrm{~mL}$ of preprepared cultures of bacteria at $\mathrm{OD}_{600}=0.3$. Then, $75 \mathrm{~mL}$ of sterile water was added to obtain $60 \%$ medium moisture. The bioreactor was connected to the rest of the apparatus and placed in a thermostatic cabinet at $30^{\circ} \mathrm{C}$. The culture was incubated for 4 days with continuous gas exchange under $60 \%$ humidity. The air pump, guaranteed gas exchange and sterile flow of air in the chamber, was turned on for 5 min with 30 min intervals. Then, $0.1 \mathrm{~g}$ of the substrate (anti-3-methyl-octane-1,4-diol (1a) or syn-3-methyl-octane-1,4-diol (1b)) dissolved in $2.5 \mathrm{~mL}$ of acetone and $2.5 \mathrm{~mL}$ of water was sprayed onto the culture. Samples were extracted after 2, 3, 4, 5 and seven days and checked by GC to estimate the progress of the biotransformation.

\subsection{Design of the Bioreactor}

The SSF bioreactor is based on calculating the voltage measurement. A Raspberry Pi Zero W was connected to a 10-bit analog-to-digital converter MCP3008 and to an optoisolated two-channel relay. For both relays, as a control signal, $3.3 \mathrm{~V}$ signal from a GPIO pins was used. Relays were used to control two $4.8 \mathrm{~W}$ air pumps with maximal efficiency of $2 \times 270 \mathrm{~L} / \mathrm{h}$ and continuous regulation. Two graphite electrodes, sensor with a probe for measuring soil moisture Waveshare 9527, steel tube for temperature sensor, one glass capillary with tapered tip responsible for water additions and two glass capillary with microbiological filters with $0.2 \mu \mathrm{m}$ pore size for gas exchange were placed in the bioreactor chamber. To minimize the impact of electric current, the humidity sensor electrodes were connected to the MOSFET transistor as a switch. Microbiological filters with $0.2 \mu \mathrm{m}$ input and output as well as microbiological filters with input of air in bottles with sterile water guaranteed sterile air conditions. To connected air wires Teflon hoses were used. The chamber was made of polypropylene to be sterilized. The dimensions of the vessel were $120 \mathrm{~mm} \times 85 \mathrm{~mm} \times 65 \mathrm{~mm}$ and were selected to be able to work in the chamber under sterile conditions. The graphite electrodes connected to MCP3008 were $22 \mathrm{~mm}$ in diameter and $160 \mathrm{~mm}$ in height (Figures S14-S17 SI).

\subsection{Extraction Methods}

\subsubsection{Simple Extraction}

When the biotransformation was completed, growth medium with microorganisms was transferred into a $1000 \mathrm{~mL}$ flask and extracted three times with ethyl acetate $(100 \mathrm{~mL})$. During the first extraction, the reaction mixture was shaken with solvent for $4 \mathrm{~h}$, and then the organic phase was filtered under reduced pressure. Subsequent extractions were carried out by analogy lasting $2 \mathrm{~h}$ and $1 \mathrm{~h}$, respectively. The collected organic phase was transferred into a flask and dehydrated by anhydrous $\mathrm{MgSO}_{4}$. Then, it was filtered through a paper filter, and the solvent was evaporated under reduced pressure. 


\subsubsection{Steam Distillation}

After biotransformation, growth medium with biomass was transferred into a $500 \mathrm{~mL}$ round-bottom flask, and then $200 \mathrm{~mL}$ of distilled water was added. The flask was connected to the distillation apparatus. Distillation was carried out for $2 \mathrm{~h}$, and the distillate was collected into a $250 \mathrm{~mL}$ round-bottom flask. The distillates were transferred to a $500 \mathrm{~mL}$ splitter and then extracted three times with $80 \mathrm{~mL}$ of ethyl acetate. Then, the extract was dried with anhydrous $\mathrm{MgSO}_{4}$, and the organic solvent was evaporated under reduced pressure.

\subsubsection{Steam Distillation from the Extract}

In this modification of steam distillation, the content of the bioreactor vessel was transferred into a $1000 \mathrm{~mL}$ flask and extracted three times with ethyl acetate $(100 \mathrm{~mL})$. During the first extraction, the reaction mixture was shaken with solvent for $4 \mathrm{~h}$, and then the organic phase was filtered under reduced pressure. Subsequent extractions were carried out by analogy lasting $2 \mathrm{~h}$ and $1 \mathrm{~h}$. The organic phase was transferred to a flask and dehydrated by anhydrous $\mathrm{MgSO}_{4}$. Then, it was filtered through a paper filter, and the solvent was evaporated under reduced pressure. The extract obtained from three extractions was placed in a $250 \mathrm{~mL}$ round-bottom flask, and $100 \mathrm{~mL}$ of distilled water was added and connected to the distillation apparatus. Distillation was carried out for $2 \mathrm{~h}$, and $250 \mathrm{~mL}$ of distillate was collected. The distillates were transferred to a $500 \mathrm{~mL}$ splitter and then extracted three times with $80 \mathrm{~mL}$ of ethyl acetate. Then, the extract was dried with anhydrous $\mathrm{MgSO}_{4}$, and the organic solvent was evaporated under reduced pressure.

\subsubsection{Extraction with a Dryng Apparatus}

After biotransformation, reaction mixture was placed in a $500 \mathrm{~mL}$ round-bottom flask, and then $200 \mathrm{~mL}$ of distilled water was added. The sample flask was heated for $2 \mathrm{~h}$. The vapors were condensed by means of a cold refrigerant. After extraction, $1 \mathrm{~mL}$ of cyclohexane containing biotransformation products was collected.

\subsection{Analysis Procedure}

Separation of the diastereoisomeric mixture of cis/trans-whisky lactones and chemical reduction of whisky lactones to corresponding diols were controlled by thin layer chromatography (TLC), using aluminum fail plates coated with silica gel. Compounds were detected by spraying the plates with $1 \% \mathrm{Ce}\left(\mathrm{SO}_{4}\right)_{2}$ and $2 \% \mathrm{H}_{3}\left[\mathrm{P}\left(\mathrm{Mo}_{3} \mathrm{O}_{10}\right)_{4}\right]$ in $10 \% \mathrm{H}_{2} \mathrm{SO}_{4}$. Gas chromatography analysis (GC, FID, carrier gas $\mathrm{H}_{2}$ ) was carried out on Agilent Technologies 7890N (GC System, Santa Clara, CA, USA). Enantiomeric excesses of the products were determined on chiral column Cyclosil-B ( $30 \mathrm{~m} \times 0.25 \mathrm{~mm} \times 0.25 \mu \mathrm{m}$, Santa Clara, CA, USA) according to the next temperature program: $80{ }^{\circ} \mathrm{C}, 160^{\circ} \mathrm{C}\left(3{ }^{\circ} \mathrm{C} / \mathrm{min}\right), 250{ }^{\circ} \mathrm{C}\left(20^{\circ} \mathrm{C} / \mathrm{min}\right)$ ( $3 \mathrm{~min}$ ). Samples $(2 \mu \mathrm{L})$ were injected with split 9:1; the flow of carrying gas was $1 \mathrm{~mL} / \mathrm{min}$. The total run time was $34.0 \mathrm{~min}$. Retention times were established as follow: $t_{R}=20.74 \mathrm{~min}$ for trans $-(+)-(4 S, 5 R)(\mathbf{2 a}), \mathrm{t}_{\mathrm{R}}=21.05 \mathrm{~min}$ for trans- $(-)-(4 R, 5 S)(\mathbf{2} \mathbf{b}), \mathrm{t}_{\mathrm{R}}=22.42 \mathrm{~min}$ for cis$(-)-(4 S, 5 S)(2 \mathrm{c}), \mathrm{t}_{\mathrm{R}}=22.54 \mathrm{~min}$ for cis- $(+)-(4 R, 5 R)(\mathbf{2 d})$ (Figure S1 SI). The substrates were determined on the chiral column CP-Chirasil L-Val $(25 \mathrm{~m} \times 0.25 \mathrm{~mm} \times 0.12 \mu \mathrm{m}$, Santa Clara, CA, USA) according to the next temperature program: $80^{\circ} \mathrm{C}, 165^{\circ} \mathrm{C}\left(3{ }^{\circ} \mathrm{C} / \mathrm{min}\right), 200{ }^{\circ} \mathrm{C}$ $\left(20^{\circ} \mathrm{C} / \mathrm{min}\right)(1 \mathrm{~min})$. Samples $(2 \mu \mathrm{L})$ were injected with split 9:1; the flow of carrying gas was $1 \mathrm{~mL} / \mathrm{min}$. The total run time was $31.0 \mathrm{~min}$. Retention times were established as follow: $t_{R}=18.553$ for anti-3-methyl-octane-1,4-diol (1a), $t_{R}=18.630$ min for syn-3-methyloctane-1,4-diol (1b). The structures of the compounds were confirmed on the basis of ${ }^{1} \mathrm{H}$ NMR and ${ }^{13} \mathrm{C}$ NMR, which were recorded for $\mathrm{CDCl}_{3}$ solutions on a Bruker Avance DRX $600(600 \mathrm{MHz})$ spectrometer (Billerica, MA, USA). IR spectra were determined using FTIR Thermo-Mattson IR 300 Spectrometer. Optical rotations were measured on a Jasco P-2000 Polarimeter. 


\subsection{Moisiture Analysis}

To ensure maximum chemical protection and to minimalize the impact of metals on microorganisms, we decided to use graphite electrodes to measure the moisture content. A sensor with a probe for measuring soil moisture Waveshare 9527 was also checked to compare them with graphite electrodes and determine which electrodes would be better for controlling the humidity. The moisture sensor was calibrated using an oil cake with known water content. The bioreactor chamber was placed in a temperature controller at an air temperature of $30^{\circ} \mathrm{C}$. The preliminary study showed that an equilibrium state was established in $15 \mathrm{~min}$, so the measurements were carried out after this time. Water was added to the bioreactor vessel in a liquid state by spraying through a septum with small holes $(\mathrm{d}=1 \mathrm{~mm})$. The moisture sensor monitored the oil cake moisture and water was added automatically when the humidity level in the bioreactor vessel decreased by $3 \%$ from the set point. Sensor measurements were fluctuating in range $\pm 1 \%$.

The relation between the water additive and voltage was determined using an analog digital converter. A separate curve depending on the moisture from the analog to digital converter was designed for each of the oilcakes. We also examine the effect of temperature and electrode distance on the response of the sensor. When we increased the moisture, the resistance between electrodes decreased, which resulted in more voltage. Electrodes were placed at a distance of $3 \mathrm{~cm}$ from each other and submerged in the culture to a depth of $1 \mathrm{~cm}$. Measurement of the water content depending on the conductivity was carried out by adding water successively, which corresponds to $5 \%$ to $90 \%$ by increasing the oilcake content by 5 to $50 \mathrm{~g}$. Research was carried out at a temperature of $30^{\circ} \mathrm{C}$. Moisture was calculated by the following Equation (1) which allows to calculate the amount of water required to achieve the desired humidity value taking into consideration the water contained presently in the cake.

$$
W w=O w * \frac{W}{100 \%-W}-O w * M w
$$

Ww-Water weight $[\mathrm{g}]$

Ow-Oilcake weight $[\mathrm{g}]$

W-Moisture content that we need to obtain [\%]

Mw-Moisture contet in oilcakes [\%]

The amount of water added ranged from $2.6 \mathrm{~g}$ for $5 \%$ moisture to $450 \mathrm{~g}$ for $90 \%$ moisture. Each addition of water required 15 min of waiting for water absorption. Then, measurements were carried out every $10 \mathrm{~s}$ until 10 matching results were obtained.

\subsection{Software}

In the presented bioreactor, we used a Raspbian Stretch Linux distribution specifically designed for Raspberry Pi. To control the relay and MCP3008, Python programming was used. When the moisture value was too low, the resistance between the graphite electrodes increased, and one of the GPIO pins that controlled the relay changed the LOW/HIGH state. The air pumps, enabled by the relay, pumped sterile air to the bottle with water, the pressure pushed water to capillary, and consequently, the medium was moistened. The second pump was used to exchange the gas by removal of carbon dioxide and other gases and was controlled by the GPIO pins switched on at certain intervals. The temperature sensor TMP36GT9Z was used only for remote temperature reading and was not connected to the heating cabinet. All data from sensors were collected and sent to a server.

\section{Conclusions}

The byproducts from the oil industry can be used as a valuable microbial medium for the bacterial oxidation process, leading from diols to whisky lactones. Biotransformations carried out on a preparative scale delivered corresponding enantiomerically enriched isomers trans-(+)-(4S,5R) (2a), cis- $(-)-(4 S, 5 S)(\mathbf{2} \mathbf{c})$ and cis- $(+)-(4 R, 5 R)(\mathbf{2 d})$. Among the different 
oil cakes tested, biotransformations carried out on linseed cake were characterized by a high conversion and stereoselectivity. During the research, it was confirmed that biotransformations should be carried out separately for anti- (1a) and syn-3-methyl-octane-1,4-diol (1b) because the oxidation of the diastereoisomeric mixture of diols was characterized by low stereoselectivity. Steam distillation followed by simple extraction with the use of organic solvents was proven to be the most efficient method of extracting products after biotransformation. This method allowed for the extraction of whisky lactones without the fats in the oilcake. In our opinion, our bioreactor prototype is definitively a better alternative to classic biotransformations performed in Erlenmeyer flasks. The measurements of moisture in the solid medium using graphite electrodes were satisfactory, and the irrigation and gas exchange system worked properly. Our results showed that by using simple solutions, it is possible to create a fully functional bioreactor prototype.

Supplementary Materials: The following are available online at https:/ / www.mdpi.com/2073-434 4/11/3/320/s1, Figure S1: Chromatogram of the mixture of trans and cis whisky lactone, Figure S2: ${ }^{1} \mathrm{H}$ NMR spectrum of trans-whisky lactone, Figure S3: ${ }^{13} \mathrm{C}$ NMR spectrum of trans-whisky lactone, Figure S4: IR spectrum of trans-whisky lactone, Figure S5: ${ }^{1} \mathrm{H}$ NMR spectrum of cis-whisky lactone, Figure S6: ${ }^{13} \mathrm{C}$ NMR spectrum of cis-whisky lactone, Figure S7: IR spectrum of cis-whisky lactone, Figure S8: $1 \mathrm{H}$ NMR spectrum of anti-3-methyl-octane-1,4-diol, Figure S9: ${ }^{13} \mathrm{C}$ NMR spectrum of anti-3-methyl-octane-1,4-diol, Figure S10: IR spectrum of anti-3-methyl-octane-1,4-diol, Figure S11: ${ }^{1} \mathrm{H}$ NMR spectrum syn-3-methyl-octane-1,4-diol, Figure S12: ${ }^{13} \mathrm{C}$ NMR spectrum syn-3-methyloctane-1,4-diol, Figure S13: IR spectrum syn-3-methyl-octane-1,4-diol, Figure S14: A bioreactor vessel with graphite electrodes, a vessel with water, air and water pumps, Figure S15: Control system in the plastic cover, Figure S16: Moisture sensor, Figure S17: Bacteria in the linseed cake.

Author Contributions: Conceptualization, D.H., J.P., F.B.; methodology, D.H., J.P., E.S., T.O., F.B.; formal analysis, D.H., F.B.; investigation, D.H., J.P.; resources, D.H., F.B.; writing-original draft preparation, D.H., J.P., E.S.; writing-review and editing, F.B.; visualization, D.H., E.S.; supervision, F.B.; All authors have read and agreed to the published version of the manuscript.

Funding: This research and APC was funded by the project "UPWR 2.0:international and interdisciplinary program of development of Wrocław University of Environmental and Life Sciences", co-financed by the European Social Fund under the Operational Program Knowledge Education Development, under contract No. POWR.03.05.00-00-Z062/18 of 4 June 2019. The work was supported by Wroclaw Centre of Biotechnology, program The Leading National Research Centre (KNOW) for years 2014-2018.

Data Availability Statement: The data presented in this study are available on request from the corresponding author.

Acknowledgments: We would like to thank American Journal Experts (AJE) for providing the editing service.

Conflicts of Interest: The authors declare no conflict of interest.

\section{References}

1. Pandey, A. Solid-state fermentation. Biochem. Eng. J. 2003, 13, 81-84. [CrossRef]

2. Kapilan, R. Solid state fermentation for microbial products: A review. Appl. Sci. Res. 2015, 7, 21-25.

3. Pandey, A.; Soccol, C.R.; Mitchell, D. New developments in solid state fermentation: I-bioprocesses and products. Process. Biochem. 2000, 35, 1153-1169. [CrossRef]

4. Singhania, R.R.; Patel, A.K.; Soccol, C.R.; Pandey, A. Recent advances in solid-state fermentation. Biochem. Eng. J. 2009, 44, 13-18. [CrossRef]

5. Rodrı, S. Application of solid-state fermentation to food industry-A review. J. Food Eng. 2006, 76, $291-302$.

6. Ramachandran, S.; Singh, S.K.; Larroche, C.; Soccol, C.R.; Pandey, A. Oil cakes and their biotechnological applications-A review. Bioresour. Technol. 2007, 98, 2000-2009. [CrossRef]

7. Soccol, C.R.; da Costa, E.S.F.; Letti, L.A.J.; Karp, S.G.; Wojciechowski, A.L.; de Souza Vandenberghe, L.P. Recent developments and innovations in solid state fermentation. Biotechnol. Res. Innov. 2017, 1, 52-71. [CrossRef]

8. Kannan, T.R.; Kanagaraj, C. Molecular characteristic of $\alpha$-amylase enzymes producing from Bacillus lichenformis (JQ946317) using solid state fermentation. Biocatal. Agric. Biotechnol. 2019, 20, 1-6. [CrossRef] 
9. Liguori, R.; Amore, A.; Faraco, V. Waste valorization by biotechnological conversion into added value products. Appl. Microbiol. Biotechnol. 2013, 97, 6129-6147. [CrossRef] [PubMed]

10. Papagianni, M. Recent Advances in Solid-State Fermentation Applications for the Food Industry. Curr. Biochem. Eng. 2013, 1, 2-8. [CrossRef]

11. Rodríguez Madrera, R.; Pando Bedriñana, R.; Suárez Valles, B. Production and characterization of aroma compounds from apple pomace by solid-state fermentation with selected yeasts. LWT Food Sci. Technol. 2015, 64, 1342-1353. [CrossRef]

12. Raghavarao, K.S.M.S.; Ranganathan, T.V.; Karanth, N.G. Some engineering aspects of solid-state fermentation. Biochem. Eng. J. 2003, 13, 127-135. [CrossRef]

13. Castilho, L.R.; Polato, C.M.S.; Baruque, E.A.; Sant'Anna, G.L.; Freire, D.M.G. Economic analysis of lipase production by Penicillium restrictum in solid-state and submerged fermentations. Biochem. Eng. J. 2000, 4, 239-247. [CrossRef]

14. Boratyński, F.; Szczepańska, E.; Grudniewska, A.; Skalny, B.; Olejniczak, T. A novel approach for microbial synthesis of enantiomerically pure whisky lactones based on solid-state fermentation. Molecules 2018, 23, 659. [CrossRef]

15. Chreptowicz, K.; Wielechowska, M.; Główczyk-Zubek, J.; Rybak, E.; Mierzejewska, J. Production of natural 2-phenylethanol: From biotransformation to purified product. Food Bioprod. Process. 2016, 100, 275-281. [CrossRef]

16. Nagy, V.; Toke, E.R.; Keong, L.C.; Szatzker, G.; Ibrahim, D.; Omar, I.C.; Szakács, G.; Poppe, L. Kinetic resolutions with novel, highly enantioselective fungal lipases produced by solid state fermentation. J. Mol. Catal. B Enzym. 2006, 39, 141-148. [CrossRef]

17. Marie, L.; Gori, K.; Agerlin, M.; Jespersen, L.; Arneborg, N. Flavour compound production by Yarrowia lipolytica, Saccharomyces cerevisiae and Debaryomyces hansenii in a cheese-surface model. Int. Dairy J. 2011, 21, 970-978.

18. Marco, B.A.D.; Rechelo, B.S.; Tótoli, E.G.; Kogawa, A.C.; Regina, H.; Salgado, N. Evolution of green chemistry and its multidimensional impacts: A review. Saudi Pharm. J. 2019, 27, 1-8. [CrossRef]

19. Braga, A.; Belo, I. Biotechnological production of gamma-decalactone, a peach like aroma, by Yarrowia lipolytica. World J. Microbiol. Biotechnol. 2016, 32, 169. [CrossRef]

20. Ashok, A.; Doriya, K.; Rao, D.R.M.; Kumar, D.S. Design of solid state bioreactor for industrial applications: An overview to conventional bioreactors. Biocatal. Agric. Biotechnol. 2017, 9, 11-18. [CrossRef]

21. Rayhane, H.; Josiane, M.; Gregoria, M.; Yiannis, K.; Nathalie, D.; Ahmed, M.; Sevastianos, R. From flasks to single used bioreactor: Scale-up of solid state fermentation process for metabolites and conidia production by Trichoderma asperellum. J. Environ. Manage. 2019, 252, 109496. [CrossRef]

22. Maga, J.A. Oak lactones in alcoholic beverages. Food Rev. Int. 1996, 12, 105-130. [CrossRef]

23. Günther, C.; Mosandl, A. Stereoisomere Aromastoffe, XII. 3-Methyl-4-octanolid—“Quercuslacton, Whiskylacton"-Struktur und Eigenschaften der Stereoisomeren. Liebigs Ann. der Chemie 1986, 1986, 2112-2122. [CrossRef]

24. Abbott, N.; Puech, J.L.; Bayonove, C.; Baumes, R. Determination of the Aroma Threshold of the cis and trans Racemic Forms of $\beta$-Methyl- $\gamma$-Octalactone by Gas Chromatography-Sniffing Analysis. Am. J. Enol. Vitic. 1995, 46, 292-294.

25. Suzukt, Y.; Mori, W.; Ishizone, H.; Naito, K.; Honda, T. Concise enantiospecific syntheses of (+)-Eldanolide and (-)-cis-whisky lactone. Tetrahedron Lett. 1992, 33, 4931-4932. [CrossRef]

26. Ito, K.; Yoshitake, M.; Katsuki, T. Chiral bipyrindine and biquinoline ligands: Their asymmetric synthesis and application to the synthesis of trans-whisky lactone. Tetrahedron 1996, 52, 3905-3920. [CrossRef]

27. Jiang, X.; Fu, C.; Ma, S. A concise synthesis of (-)- and (+)-trans-whisky lactones. Eur. J. Org. Chem. 2010, $2010,687-693$. [CrossRef]

28. Pisani, L.; Superchi, S.; D’Elia, A.; Scafato, P.; Rosini, C. Synthetic approach toward cis-disubstituted $\gamma$ - and $\delta$-lactones through enantioselective dialkylzinc addition to aldehydes: Application to the synthesis of optically active flavors and fragrances. Tetrahedron 2012, 68, 5779-5784. [CrossRef]

29. Armstrong, A.; Ashraff, C.; Chung, H.; Murtagh, L. Oxidative rearrangement of 2-alkoxy-3,4-dihydro-2H-pyrans: Stereocontrolled synthesis of 4,5-cis-disubstituted tetrahydrofuranones including whisky and cognac lactones and crobarbatic acid. Tetrahedron 2009, 65, 4490-4504. [CrossRef]

30. Xie, H.; Lu, J.; Gul, Y.; Gao, L.; Song, Z. (HMe2SiCH2)2: A useful reagent for B(C6F5)3-catalyzed reduction-lactonization of keto acids: Concise syntheses of (-)-cis-whisky and (-)-cis-cognac lactones. Synlett 2017, 28, 2453-2459.

31. Boratyński, F.; Smuga, M.; Wawrzeńczyk, C. Lactones 42. Stereoselective enzymatic/microbial synthesis of optically active isomers of whisky lactone. Food Chem. 2013, 141, 419-427. [CrossRef]

32. Boratyński, F.; Szczepańska, E.; Grudniewska, A.; Olejniczak, T. Microbial kinetic resolution of aroma compounds using solid-state fermentation. Catalysts 2018, 8, 28. [CrossRef]

33. Boratyński, F.; Dancewicz, K.; Paprocka, M.; Gabryś, B.; Wawrzeńczyk, C. Chemo-enzymatic synthesis of optically active $\gamma-$ and $\delta$-decalactones and their effect on aphid probing, feeding and settling behavior. PLoS ONE 2016, 11, e0146160. [CrossRef]

34. Boratyński, F.; Szczepańska, E.; De Simeis, D.; Serra, S.; Brenna, E. Bacterial biotransformation of oleic acid: New findings on the formation of $\gamma$-dodecalactone and 10-ketostearic acid in the culture of Micrococcus luteus. Molecules 2020, 25, 3024. [CrossRef]

35. Boratyński, F.; Pannek, J.; Walczak, P.; Janik-Polanowicz, A.; Huszcza, E.; Szczepańska, E.; Martin-Rojas, E.; Olejniczak, T. Microbial alcohol dehydrogenase screening for enantiopure lactone synthesis: Down-stream process from microtiter plate to bench bioreactor. Process. Biochem. 2014, 49, 1637-1646. [CrossRef]

36. Graminha, E.B.N.; Gonçalves, A.Z.L.; Pirota, R.D.P.B.; Balsalobre, M.A.A.; Da Silva, R.; Gomes, E. Enzyme production by solid-state fermentation: Application to animal nutrition. Anim. Feed Sci. Technol. 2008, 144, 1-22. [CrossRef] 
37. Gutierrez, C.; Rubilar, M.; Jara, C.; Verdugo, M.; Sineiro, J.; Shene, C. Flaxseed and Flaxseed cake as a source of compounds for food industry. J. Soil Sci. Plant. Nutr. 2009, 10, 454-463. [CrossRef]

38. Stasiniewicz, T.; Niwińska, B.; Strzetelski, J.; Kowalczyk, J.; Maciaszek, K.; Bilik, K. Nutritive value of evening primrose (Oenothera paradoxa) cake for ruminants. J. Anim. Feed Sci. 1998, 7, 187-195. [CrossRef]

39. Liu, J.; Du, C.; Beaman, H.; Monroe, M. Characterization of phenolic acid antimicrobial and antioxidant structure-property relationships. Pharmaceutics 2020, 21, 419. [CrossRef]

40. Wilkinson, K.L.; Elsey, G.M.; Prager, R.H.; Tanaka, T.; Sefon, M.A. Precursors to oak lactone. Part 2: Synthesis, separation and cleavage of several $\beta$-D-glucopyranosides of 3-methyl-4-hydroxyoctanoic acid. Tetrahedron 2004, 60, 6091-6100. [CrossRef] 